\title{
Synoptic measures of sediment contamination, toxicity and infaunal community composition (the Sediment Quality Triad) in San Francisco Bay
}

\author{
P. M. Chapman ${ }^{1}$, R. N. Dexter ${ }^{2}$ \& E. R. Long ${ }^{3}$ \\ 'E.V.S. Consultants, 195 Pemberton Avenue, North Vancouver, British Columbia V7P 2R4, Canada \\ ${ }^{2}$ E.V.S. Consultants, 2335 Eastlake Avenue East, Seattle, Washington 98102, USA \\ ${ }^{3}$ Ocean Assessments Division, N/OMA 32X2, US National Oceanic and Atmospheric Administration, 7600 Sand Point Way N.E., \\ Seattle, Washington 98115 , USA
}

\begin{abstract}
The utility of the Sediment Quality Triad was assessed in determining pollution-induced degradation. This approach consists of synoptic measurements of sediment contamination by chemical analyses, sediment toxicity through bioassays, and benthic infaunal community structure through taxonomic analyses of macroinfauna. Each component of the Triad complements the other 2 and together all 3 components provide an objective assessment of pollution-induced degradation. The underlying hypothesis is that no component can be used to predict measurements of the other 2 components. Sediment samples were collected at 3 stations at each of 3 sites in San Francisco Bay, USA - Islais Waterway, near Oakland, and in San Pablo Bay - and subjected to 4 separate, replicated sediment bioassays, comprehensive sediment chemistry analyses (no replication), and replicated benthic infaunal analyses. Chemistry analysis indicated that the Islais Waterway site was more contaminated by a number of potentially toxic substances than the Oakland site, while the latter was slightly more contaminated that the San Pablo Bay site. However, even the highest chemical concentrations measured were murh inwer than those measured in other areas of the West Coast where sediment toxicity and modified infauna have been observed; thus the chemical data by themselves did not indicate major environmental effects. Bioassays indicated that sediments at Islais Waterway were most toxic, those at San Pablo Bay least toxic, and those at Oakland intermediate. The bioassay data, if taken alone, would have predicted that contamination at the Islais Waterway site was greater than actually measured. Infaunal analyses indicated that communities at Islais Waterway were the most altered while those at Oakland were slightly less altered, relative to San Pablo Bay. If sediment chemistry and toxicity data had not been collected, these benthic community differences could have been attributed to only substantial sediment texture differences observed among the 3 sites. Using a composite index developed from the 3 Triad components, the Islais Waterway site could be considered to be $58 \times$ more degraded than the San Pablo Bay site, the site most removed from direct anthropogenic influences. By the same index, the Oakland site was $1.4 \times$ more degraded than the San Pablo Bay site.
\end{abstract}

\section{INTRODUCTION}

Recently, various approaches to assessing sediment quality have been offered using benthic community structure data only (Gray 1981, Warwick 1986); sediment contamination data alone (Satsmadjis \& Voutsinou-Taliadouri 1985); benthic community data and pollution loading data (Jeffrey et al. 1985); or benthic community data and sediment contamination data (Neff et al. in press). The present study was initiated as a field trial of an approach to marine pollution assessments referred to as the Sediment Quality Triad (Long \& Chapman 1985, Chapman 1986).
The Triad consists of measures of sediment chemical contamination, toxicity and resident infauna community structure. Preliminary testing of the Triad has been conducted in Puget Sound, Washington, USA, using available data from numerous investigations (Chapman et al. 1985). Despite problems of data incompatibility, results were encouraging: the 3 types of measures provided strong and complementary evidence of the degree of pollution-induced degradation.

The Sediment Quality Triad is intended to incorporate 3 essential components to define pollutiondegraded areas: measurements to determine the presence and degree of anthropogenic contamination (i.e. 
bulk sediment chemistry); measurements that demonstrate that substances in the sediment can interfere with the normal functioning of at least some biological organisms tested in the laboratory (i.e. sediment bioassays); and assessment of in situ alteration of resident biological communities (e.g. measures of benthic infaunal community structure). Pollution-induced degradation is defined here as a biologically damaging excess of contamination.

Sediments are effective sinks of contaminants and, therefore, chemical analyses of them are useful in determining the degree and nature of contamination of a given area. However, the resulting chemical data provide little or no evidence of biological consequences of the contamination. Bioassays of bulk sediments have proven to be very useful in determining whether or not the sediments are toxic. However, since the bioassays are usually performed in worst-case laboratory situations, confirmation of effects among resident biota is needed. The Sediment Quality Triad concept evolved as a result of the realization that all 3 measurements complement each other and are needed to provide strong evidence of pollution-induced degradation.

Measurements of pollution-induced degradation would be greatly facilitated if any one of the above Triad components was sufficient alone to define problem areas. For instance, if sediment chemical concentrations that were universally known to be toxic could be defined for all chemicals and combinations of chemicals, or if bioassay results could be reliably related to in situ impacts, or if benthic population studies could identify alterations in populations that were absolutely due only to chemical contamination, then an integrated assessment such as the Sediment Quality Triad would be unnecessary. The hypothesis tested in the present study was that none of these individual measures presently suffices to define pollution-induced degradation and as a consequence, only through measurement of all 3 components of the Triad and examination of the preponderance of evidence can 'problem' areas be identified. The criterion for accepting the hypothesis was that no individual component of the Triad could be used consistently and with the same degree of accuracy to predict the behavior of the other 2 Triad components.

\section{MATERIALS AND METHODS}

Approach. The present study was conducted at 3 sites in San Francisco Bay, California, USA. Relatively little research on toxic chemicals (especially organic compounds) and their effects has been performed in this extremely important Pacific Coast estuary. There- fore, sites were chosen based on best available information to represent presumably low, moderate and high levels of chemical contamination. Sites chosen, in order of presumed increasing anthropogenic influences, were: San Pablo Bay (SP), off Oakland (OA) and Islais Waterway (IS) (Fig. 1). The San Pablo Bay site is relatively distant from point sources of contamination, is considered to be among the least chemically contaminated parts of the San Francisco Bay system (Spies et al. 1985), and was used as the reference site for this study. The Oakland site is near the major industrial and maritime facilities of the Oakland/Berkeley metropolitan area. The Islais Waterway site is in an industrial waterway that receives storm/sewer overflows.

Three stations were sampled in each of the 3 sites for sediment bioassay testing, benthic infaunal analyses and sediment chemistry analysis (Fig. 1). The following determinations were made: (1) detailed chemical analyses on composited surface sediments, aliquots from which were also used for bioassay testing; (2) four separate types of sediment bioassays on the composited surface sediment; (3) benthic infauna identifications of biota retained on a $1 \mathrm{~mm}$ screen. The results of these analyses were used to rank the degree of degradation of each station and each site, based on both individual measures (i.e. sediment chemistry, bioassay results and infauna characteristics) and combined measures (i.e. the Sediment Quality Triad).

Sediment collection. Sediment samples at all stations were collected with a $0.1 \mathrm{~m}^{2}$ Van Veen grab modified to minimize surface sediment disturbance during collection, and to allow easy access to the surface of the sediments in the grab. Only grabs that had achieved adequate penetration and that showed no evidence of leakage or surface distubance were retained for this study.

For the benthic infaunal samples, the entire contents of the grab, including the overlying water, were wetsieved at the study site with a $1 \mathrm{~mm}$ stainless steel screen. Residues were gently washed down, placed in polyethylene bags and preserved with $10 \%$ buffered formalin. Five replicate grabs were collected for infauna at each station, independently from those used for bioassays and chemical analyses. For the latter, the surface water was decanted to expose the undisturbed sediment surface. The upper $2 \mathrm{~cm}$ of sediment was carefully removed with a stainless steel spatula and transferred to a stainless steel bowl. When sufficient sediment had been collected from a station, the contents of the bowl were homogenized with a stainless steel spoon until no color or textural differences could be detected, and then transferred to the sample containers.

A minimum of $5 \mathrm{l}$ of sediment were transfered to new polyethylene bags and stored on ice for the bioassays 


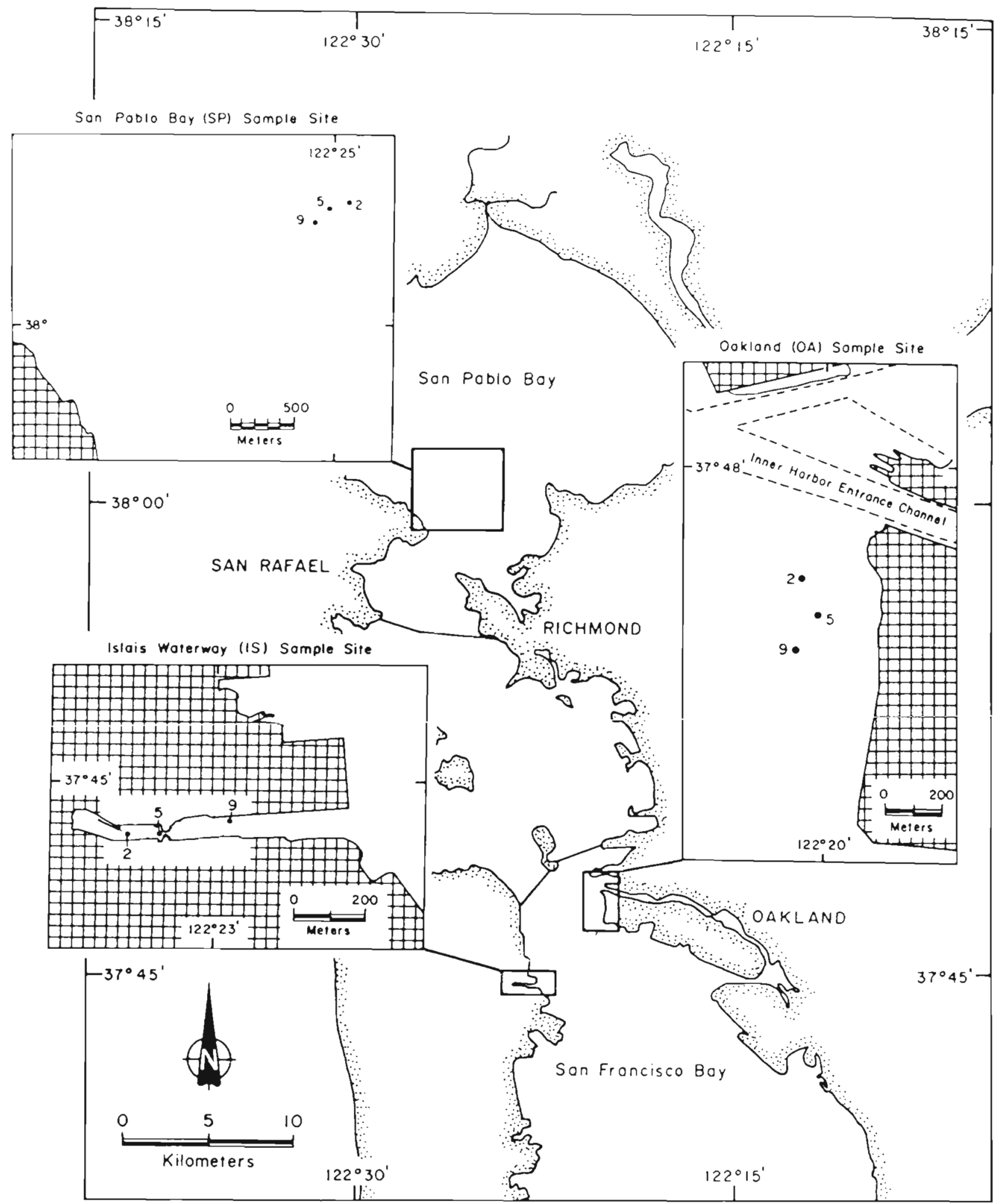

Fig. 1. Map of San Francisco Bay showing general areas sampled and locations of sampling stations within sites sampled 
Table 1. List of parameters measured in San Francisco Bay sediments

\begin{tabular}{|c|c|c|c|}
\hline Parameter & $\begin{array}{c}\text { Detection } \\
\text { limit } \\
\left(\mu \mathrm{g} \text { dry } \mathrm{kg}^{-1}\right)^{z}\end{array}$ & Parameter & $\begin{array}{c}\text { Detection } \\
\text { limit } \\
\left(\mu \mathrm{d} \text { dry } \mathrm{kg}^{-1}\right)^{\mathrm{a}}\end{array}$ \\
\hline Conventional measures & & High molecular weight & \\
\hline Grain size & $\mathrm{n} / \mathrm{a}$ & aromatic hydrocarbons & \\
\hline Total Organic Carbon (TOC) & $\mathrm{n} / \mathrm{a}$ & Benzo(a)pyrene & 8 \\
\hline Total Volatile Solids (TVS) & $\mathrm{n} / \mathrm{a}$ & Benz(e)pyrene & 8 \\
\hline Sulfides & 500 & Benz(a)anthracene & 10 \\
\hline Total solids & $\mathrm{n} / \mathrm{a}$ & Chrysene & 10 \\
\hline Major elements & & Dibenzanthrancene & 16 \\
\hline Aluminum (Al) & 12 & Fluoranthene & 4 \\
\hline Silicon (Si) & $\begin{array}{l}1.2 \\
1.2\end{array}$ & Pyrene & 4 \\
\hline Manganese $(\mathrm{Mn})$ & 0.3 & Other hydrocarbons & \\
\hline Iron $(\mathrm{Fe})$ & 1.2 & Bipheny $l^{b}$ & 4 \\
\hline Magnesium (Mg) & 0.2 & Perylene ${ }^{b}$ & 4 \\
\hline Calcium (Ca) & 0.7 & Coprostanol & 10 \\
\hline Sodium ( $\mathrm{Na}$ ) & 8.0 & Chlorinated hydrocarbons & \\
\hline Titanium (Ti) & 0.3 & Aldrin & 0.08 \\
\hline Trace elements & & alpha-Chlordane & 11.0 \\
\hline Antimony (Sb) & 5.0 & trans-Chlordane & 14.0 \\
\hline Arsenic (As) & 0.6 & $o p^{\prime}-\mathrm{DDD}$ & 0.14 \\
\hline Chromium (Cr) & 0.5 & $o p^{\prime}-\mathrm{DDE}$ & 0.25 \\
\hline Copper $(\mathrm{Cu})$ & 0.6 & $o p^{\prime}-\mathrm{DDT}$ & 0.14 \\
\hline Cadmium (Cd) & 0.2 & $p p^{\prime}-\mathrm{DDD}$ & 0.15 \\
\hline Lead $(\mathrm{Pb})$ & 0.3 & $p p^{\prime}-D D E$ & 0.08 \\
\hline Mercury $(\mathrm{Hg})$ & 0.02 & $p p^{\prime}-D D T$ & 0.10 \\
\hline Nickel (Ni) & 2.0 & Dieldrin & 0.12 \\
\hline Selenium (Se) & 0.4 & Endrin & 0.13 \\
\hline Silver (Ag) & 0.3 & Heptachlor & 0.12 \\
\hline $\operatorname{Tin}(\mathrm{Sn})$ & 2.2 & Heptachlor epoxide & 0.12 \\
\hline Thallium (Tl) & 0.3 & Hexachlorobenzene & 0.12 \\
\hline Zinc $(\mathrm{Zn})$ & 0.3 & Lindane & 0.16 \\
\hline Low molecular weight & & Mirex & 0.12 \\
\hline $\begin{array}{l}\text { Low molecular weignt } \\
\text { aromatic hydrocarbons }\end{array}$ & & trans-Nonachlor & 0.08 \\
\hline Acenapthene & 4 & Polychlorinated biphenyls (PCBs) & 2.5 \\
\hline Anthracene & 4 & & \\
\hline Naphthalene & 4 & & \\
\hline 1-methylnaphthalene & 4 & & \\
\hline 2-methylnaphthalene & 4 & & \\
\hline 2,6-dimethylnaphthalene & 4 & \multirow{5}{*}{\multicolumn{2}{|c|}{$\begin{array}{l}\text { "Instrument detection limits (IDL). Sample-specific detection } \\
\text { limits, which include any matrix effects, are provided in } \\
\text { Chapman et al. (1986) } \\
{ }^{b} \text { For consistency with other studies, biphenyl and perylene } \\
\text { are not included with the aromatic hydrocarbons }\end{array}$}} \\
\hline 2,3,5-trimethylnaphthalene & 4 & & \\
\hline Fluorene & 4 & & \\
\hline Phenanthrene & 4 & & \\
\hline 1-methylphenanthrene & 4 & & \\
\hline
\end{tabular}

and $1 \mathrm{l}$ of sediment was placed in a precleaned glass jar with a teflon cap-liner for chemical analysis. An additional $20 \mathrm{~g}$ of sediment was placed in polyethylene jars with preservative for analysis of sulfides. Samples for bioassay and chemical analyses were kept and shipped in coolers with ice, and were received at the laboratories within $4 \mathrm{~d}$ of collection.

Prior to sampling at each station, the grab was thoroughly rinsed with site water. The spatulas and bowl were rinsed with site water and with pesticide grade dichloromethane and then covered with clean aluminum foil.

Sediment physical and chemical characterization.
The parameters analysed are listed in Table 1 . Sediment grain size was determined by ASTM Method D 422-63, involving sieving of the larger (sand) fraction and sedimentation of the finer materials (silts and clays) (ASTM 1985a). Total organic carbon (TOC) was determined on each sample by high temperature combustion in pure oxygen with the carbon dioxide produced being measured in a colorimetric titration using a Coulometrics, Inc., Carbon Dioxide Coulometer (Weyerhaeuser 1985). Total volatile solids (TVS) were determined by first drying the sample at $103^{\circ} \mathrm{C}$ (which also determined the percent solids) followed by measuring the weight loss after high temperature 
$\left(550^{\circ} \mathrm{C}\right)$ combustion (APHA 1985). Grain size, TOC and TVS were reported as percentages of sediment dry weight. Sulfides were measured using distillation into zinc acetate followed by colorimetric reaction with methylene blue with determination of absorbance at $650 \mathrm{~nm}$ (EPA/CE 1981). Elemental composition was determined using the standard EPA Contract Laboratory protocol involving inductively coupled plasma emission measurements or acid digestion of the sample (Eggiman \& Betzer 1976) and measurement of the dissolved elements by atomic absorption, as appropriate (U.S. EPA 1984a). Organic compounds including coprostanol were analysed using methods similar to McLeod et al. (1984), involving a variation of EPA standard method 1625 (U.S. EPA 1984b).

The quality assurance/quality control (QA/QC) program followed the recommendations of Keith et al. (1983) and is detailed by Chapman et al. (1986). At a minimum this involved the appropriate use of analytical standards and method and reagent blanks as specified in the standard protocols.

The data from each station and calculated mean concentrations from 2 sites (OA and IS) were divided by the means of each parameter from the reference site, San Pablo Bay (SP, $n=15$ ) to yield Ratio-to-Reference (RTR) values. The RTR values served to normalize the data and were based on (but not dependent on) the assumption that the sediment conditions at the San Pablo Bay site were relatively unaltered by pollution. Presentation of the data as RTR values provided a measure of the degree of alteration at each station and site compared to the reference site, and to each other.

Toxicity testing. Four separate sediment bioassay tests were used to measure sediment toxicity. Tests were chosen to signal toxicity over a wide range of taxa and biological processes. Controls were conducted for all bioassays using clean seawater, and sediment from West Beach on Whidbey Island, Washington, USA. This site was used for collection of the bioassay test species, Rhepoxynius abronius, and is uncontaminated (Battelle 1986). The amphipod $R$. abronius $10 \mathrm{~d}$ test developed by Swartz et al. $(1982,1985)$ was used to measure acute lethality. This test was performed with 5 replicates per station, 20 amphipods per replicate. This test also has a sublethal component (avoidance of the sediments). The $48 \mathrm{~h}$ mussel Mytilus edulis larvae test described by Mitchell et al. (1985) for use in solid waste testing was used to measure sublethal effects. This test also has an acute lethal component (death of the larvae). The percent difference in survivals and in abnormal larvae was calculated relative to a clean seawater control. Behavioral effects were measured by determining the rate of reburial of the clam Macoma balthica over $48 \mathrm{~h}$ using techniques developed by McGreer (1979). This test was performed with 5 replicates, 10 clams per replicate. Reproductive impairment was measured by determining copepodite production over 4 wk by the harpacticoid copepod Tigriopus californicus, using methods developed by Misitano (1983). The test was performed with 8 replicates per station, one copepod per replicate.

Quality assurance/quality control (QA/QC) procedures used for bioassay testing followed those outlined by ASTM (1985b) and APHA (1985). Procedures employed for the Rhepoxynius abronius $10 \mathrm{~d}$ test have been verified by inter-laboratory calibration (Mearns et al. 1986).

For all bioassays, significant differences between test sediments were determined by analysis of variance and by Dunnett's procedure (Miller 1966) and Duncan's multiple range test (Steel \& Torrie 1960, Dowdy \& Wearden 1983) as appropriate. One-tailed Dunnett t-tables were used to determine significant differences between each test series and control values. For the mussel larvae bioassay, percent abnormality data were transformed using an arc sine transformation $\left(\sin ^{-1} \sqrt{\mathrm{x} / 100}\right.$ where $\mathrm{x}=$ percent abnormal larvae) prior to statistical analysis, as recommended for binomial data expressed as percentages (Steel \& Torrie 1960). For the clam reburial bioassay, the median time for reburial (ET 50) was graphically determined for each sample by log-probit methods. Lines were fitted to the data plots by eye, following standard procedures for log-probit graphs (Sprague 1969).

Ratio-to-Reference (RTR) values were calculated for the bioassay data in the same manner as with the chemistry data.

Benthic infaunal analyses. Each grab sample was screened in the field, through a $1.0 \mathrm{~mm}$ sieve, and all macroinvertebrates retained were fixed in $10 \%$ buffered formalin, with Phloxine-B added as a biological tissue stain. After $72 \mathrm{~h}$, each sample was subsequently transferred to $70 \%$ isopropanol.

Taxonomic analyses involved initially sorting each sample into major constituent taxa. Taxonomic identifications were then performed to the lowest possible level consistent with presently available references.

Quality assurance/quality control (QA/QC) procedures used for the benthic infaunal component of this study involved random resorting of $10 \%$ of all samples, and the maintenance of complete sorting, processing and laboratory records for each sample. All taxonomic identifications were verified by recognized outside experts, and a voucher collection of specimens representing each species (or lowest taxonomic unit of identification) was prepared in a permanent reference collection.

Benthic infauna data analyses were based on community descriptive statistics that were calculated for each sample, then summarized for each station $(n=5$ 
for each station). Additionally, an overall summary was established for each of the 3 sites using the data from each of the 3 stations analysed $(n=15)$. Mean values for each of the parameters described below were derived along with their respective standard error estimates

The Shannon-Weiner diversity index $(\mathrm{H})$ was calculated for each station using common logarithms. Pielou's equitability measure (Pielou 1966), defined as the ratio of diversity $(\mathrm{H})$ to the maximum possible diversity $\left(\mathrm{H}_{\max }=\log [\mathrm{s}]\right)$, was similarly calculated. A dominance measure, equivalent to the complement of equitability, was also calculated.

The numerical contribution of major taxonomic groups (i.e. Polychaeta, Mollusca, Amphipoda) were calculated as the proportions of the taxa abundance to total abundance for each of the 45 samples. Mean proportions, expressed as percentages, were also determined (with their standard errors) for stations and for each of the study sites. Numerical dominance, calculated as the complement of equitability (I-J) was related to the proportions of these major taxonomic groups.

Between-station and between-site species abundances were compared using a hierarchical, or cluster analysis. Each matrix of mean species abundance, i.e. per station and per site, was analysed to allow comparison of samples based on the similarity of species abundances and on their respective abundances. The complement of the Bray-Curtis coefficient was employed as the index of similarity in both cases. An unweighted pair-group clustering algorithm was applied to each of the resulting similarity matrices. Results were displayed as an optimally rotated dendrogram. Species richness, total abundance, numerical dominance, and relative major taxon proportions were all further expressed in terms of the Ratio-to-Reference (RTR)

\section{RESULTS}

\section{Sediment physical and chemical characterization}

Detailed results of the physical and chemical analyses are provided by Chapman et al. (1986), together with $Q A / Q C$ data. Selected portions of these data are presented in Table 2. Detailed statistical analyses of these data were not undertaken due to the lack of replication of these measurements per station.

\section{Conventional parameters}

Samples from the San Pablo Bay and Oakland sites had relatively similar texture, being dominated by the clay fraction. The one exception, Stn SP02, was the only station analysed in which the sand component dominated the sediments. The stations toward the head of Islais Waterway had very high levels of silt, constituting over $80 \%$ of sediment dry mass compared to less than $20 \%$ silt at other sites. Silt content decreased toward the mouth of the waterway and at Stn IS09 the texture was similar to that of the sediments from the San Pablo Bay and Oakland sites.

Levels of organic matter in the sediments showed trends similar to those of texture. At the San Pablo Bay and Oakland sites and at Stn IS09, the percentages of total organic carbon (TOC) in the sediments were similar and in the normal range for estuarine sediments, i.e. 1 to $2 \%$ of dry weight. The TOC content increased dramatically, however, at the 2 inner Islais Waterway stations (IS02 and IS05). The TOC content of the sediments increased in proportion to the amount of finegrained sediment in the samples.

Consistently elevated concentrations of sulfides were found only in the high TOC sediments of Islais Waterway. All stations in the waterway had detectable levels of sulfide and concentrations decreased in a gradient from the head of the waterway toward the mouth. This gradient followed the decreasing TOC content of the sediments at those stations.

\section{Major elements}

Very few differences in the concentrations of the major elements ( $\mathrm{Al}, \mathrm{Si}, \mathrm{Fe}, \mathrm{Mn}, \mathrm{Mg}, \mathrm{Ca}, \mathrm{Na}, \mathrm{Ti}$ ) were observed among the stations. The exceptions include some indication of slightly decreased levels of $\mathrm{Mn}$ and Ca in the Islais Waterway sediments.

\section{Trace elements}

Of the 13 trace elements analysed, Sb, Se and Tl were never present above the detection limits of the procedures used. Cd was detected only once, at a concentration of $1 \mathrm{mg} \mathrm{kg}^{-1}$, at Stn ISO2 at the head of Islais Waterway. The remaining elements $(\mathrm{As}, \mathrm{Cr}, \mathrm{Cu}$, $\mathrm{Ni}, \mathrm{Zn}, \mathrm{Pb}, \mathrm{Hg}, \mathrm{Sn}$, and $\mathrm{Ag}$ ) were always detected. However, as was the case with the major elements, only a few of the trace elements showed substantial differences in concentration among any stations. In Islais Waterway, the levels of $\mathrm{Pb}, \mathrm{Hg}$ and $\mathrm{Ag}$ were all much greater ( 4 to $10 x$ ) than observed at any station at the other 2 sites. The concentrations of lead were highest near the head of the waterway and appeared to decrease toward the mouth. The levels of mercury and silver both were greatest at IS05 but also decreased considerably toward the mouth of the waterway. $\mathrm{Cu}$, 


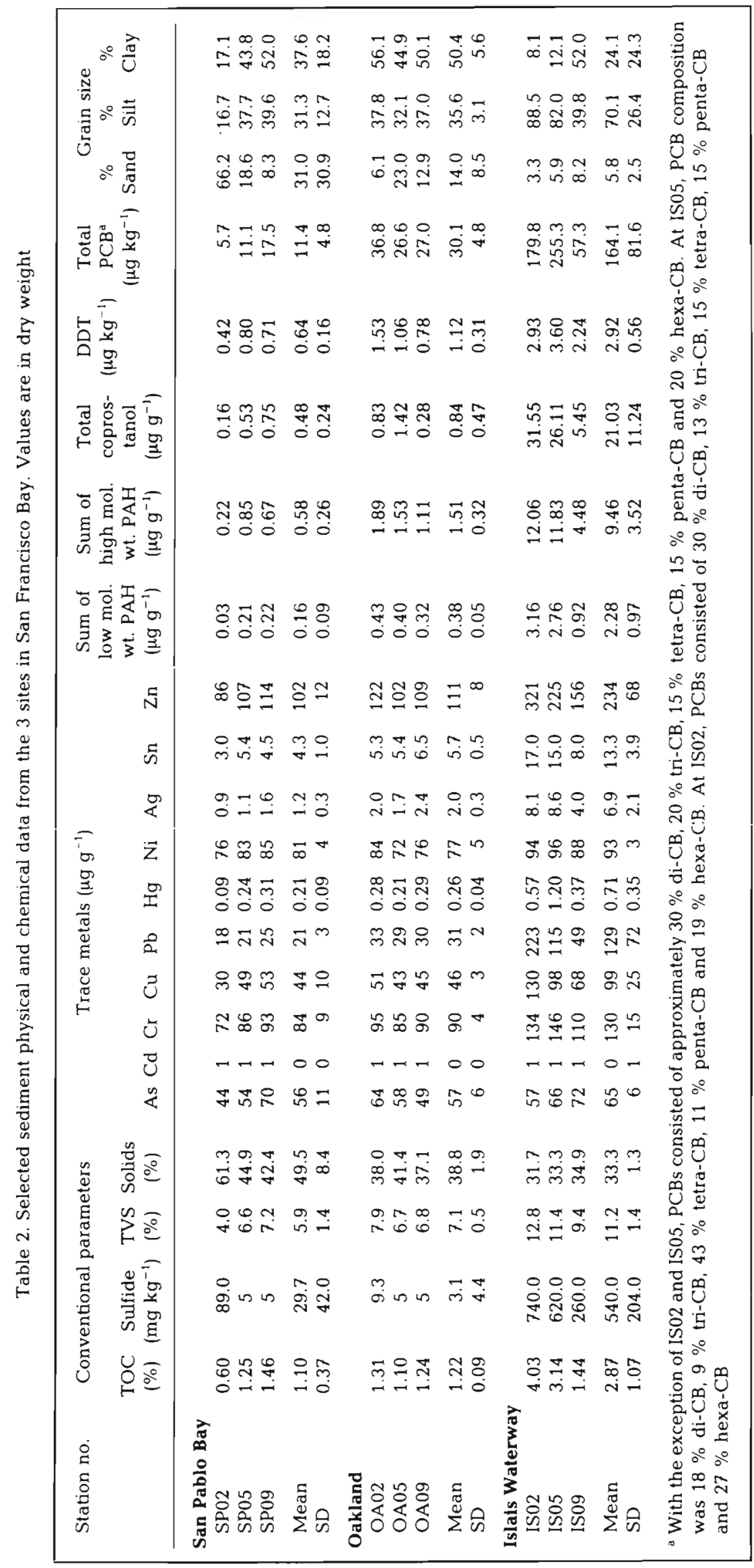


Sn and Zn were also elevated in Islais Waterway, but to a much lower extent than $\mathrm{Pb}, \mathrm{Hg}$ and $\mathrm{Ag}(2$ to $4 \times$ ). No other trace elements were present at concentrations that exceeded twice the reference site concentrations. However, the concentrations at the Oakland site were slightly greater than observed at San Pablo Bay, particularly for silver.

\section{Organic chemicals}

The organic compounds were categorized into the following 3 groups: the low molecular weight polynuclear aromatic hydrocarbons (LPAH), consisting of 2 - to 3-ring aromatic hydrocarbons and some of their methylated derivatives; the high molecular weight polynuclear aromatic hydrocarbons (HPAH), consisting of 4and 5-ringed aromatic compounds; and the chlorinated hydrocarbons, including chlorinated hydrocarbon pesticides and the polychlorinated biphenyls (PCBs). A few miscellaneous hydrocarbons, biphenyl, perylene and coprostanol (an indicator of fecal contamination) have been included with the HPAH

The Islais Waterway site was substantially $(>14 \times)$ contaminated with LPAH, while the Oakland site had slightly greater $(2 \times)$ concentrations than those observed at the San Pablo Bay site. The general trend was very similar to that of $\mathrm{Pb}$, with an apparently decreasing gradient in the concentrations of the LPAH from the head of the waterway (ISO2) toward the mouth (IS09). In the case of the LPAH, however, the extent of the contamination was much greater.

The concentrations of HPAH were substantially greater $(24 \times)$ at the stations near the head of Islais Waterway compared to the other sites, and appeared to decrease toward the mouth of the waterway. The sediments from the Oakland site were slightly $(2.5 \times)$ elevated in HPAH compared to those of the San Pablo Bay site.

Of the other organic compounds, coprostanol, a compound produced in the intestines of mammals and thus a good indicator of fecal contamination (Romberg et al. 1984), was present at very high concentrations (5.4 to $31.6 \mathrm{mg} \mathrm{kg}^{-1}$ ) in the sediments of Islais Waterway. The concentrations at the Islais Waterway site were more than 60 times greater than the concentrations observed at the San Pablo Bay site, and decreased from the head of the waterway toward the mouth. The concentrations of coprostanol at the Oakland site were roughly twice those found at the San Pablo Bay site.

Of the 17 chlorinated compounds for which analyses were performed, only 6 chlorinated pesticides and the PCBs were detected in at least one sample. Of the compounds detected, trans- and cis-chlordane and trans-nonachlor were only detected at the 2 inner sta- tions in Islais Waterway (IS02 and IS05). Only $p p^{\prime}-$ DDT, its metabolites $p p^{\prime}-D D E$ and $p p^{\prime}-D D D$ and the PCBs were routinely detected at most stations.

The spatial trends in the concentrations of the DDTs and PCBs were similar to those observed for the other compounds. However, the magnitude of the difference between San Pablo Bay and Islais Waterway was smaller ( 1 to $15 \times$ ) for both the DDTs and for the PCBs than for the PAH compounds (up to $24 \times$ ).

\section{Toxicity testing}

Bioassay results detailed by Chapman et al. (1986) are summarized in Fig. 2.

\section{Amphipod bioassay}

Mean survival during the $10 \mathrm{~d}$ amphipod bioassay ranged from a low of $5 \%$ (IS02) to a high of $96 \%$ (SP05). Mean survival in the sediment control was $94 \%$. Results of the analysis of variance indicated that significant differences in survival occurred $(F=20.5$, $\mathrm{p}=0.005$ ). Survival in the sediments from the Islais Waterway site, and for 2 out of 3 Islais Waterway stations sampled, was significantly lower $(p=0.05)$ than that for the control. In contrast, none of the stations from the San Pablo Bay and Oakland sites had a mean survival significantly lower $(p=0.05)$ than the control.

Mean avoidance in the test sediments ranged from a high of $37 \%$ (IS02) to a low of $2 \%$ (OA05). Mean avoidance in the sediment control was $6.5 \%$. Results of the analysis of variance indicated that significant differences in avoidance occurred ( $F=13.6, p=0.005)$. Significantly higher avoidance than for the control $(p=0.05)$ was determined for Islais Waterway Stn IS02.

Water quality parameters during testing were: temperature, 14.5 to $16.5^{\circ} \mathrm{C}$; salinity, 27 to $30 \mathrm{ppt}$; $\mathrm{pH}, 7.9$ to $8.4 ; \mathrm{DO}$, greater than $5.0 \mathrm{mg} \mathrm{l}^{-1}$. Interstitial salinity values at test initiation ranged from 25 to $36 \mathrm{ppt}$ and were lowest in the sediments collected at the head of Islais Waterway

Mussel larvae bioassay

Mean survival during the $48 \mathrm{~h}$ mussel larvae bioassay, relative to the seawater control, ranged from 51 to $83 \%$ for the San Pablo Bay samples, 24 to $49 \%$ for the Oakland samples, and 3 to $14 \%$ for the Islais Waterway samples. Relative survival in the sediment control was $73 \%$ of the seawater control. Results of the analysis of variance indicated that significant differ- 
INCREASING TOXICITY

$\because \because \because \because \because \because \because \because \because \because \because \because \because \because \because \because \because \because \because \because \because$

AMPHIPOD

\begin{tabular}{lcccccc} 
SP05 & $\begin{array}{c}\text { Sediment } \\
\text { Control }\end{array}$ & SP02 & OA05 & SP09 & \\
19.2 & 18.8 & 18.2 & 17.4 & 1505 & 1509 \\
& & & & 15.2 & 12.6 \\
\hline
\end{tabular}

1502

1.0

- 10 d survival (per 20 exposed)

- daily avoidance

(per 20 exposed)

$\begin{array}{cccccccc}\text { OA05 SP09 } & \text { IS09 } & \text { OA02 SP02 } & \begin{array}{l}\text { Sediment } \\ \text { Control }\end{array} & \text { IS05 } & \text { OA09 } \\ 0.4 & 0.5 & 0.6 & 0.7 & 1.1 & 1.3 & 1.7 & 1.9\end{array}$

\section{MUSSEL LARVAE}

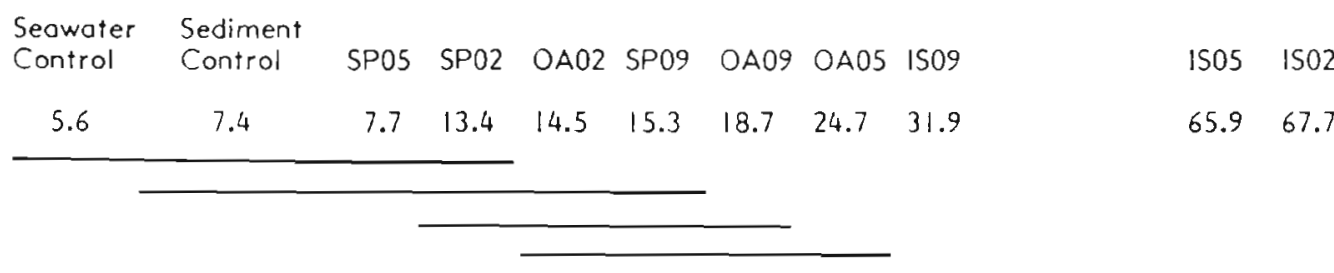

percent abnoring of $48 \mathrm{~h}$

\begin{tabular}{|c|c|c|c|c|c|c|c|c|c|c|}
\hline $\begin{array}{l}\text { Seawater } \\
\text { Conitoil }\end{array}$ & SPOS & $\begin{array}{l}\text { Sediment } \\
\text { Coniroi }\end{array}$ & $5 P 02$ & SPOY & OAOLZ & OAO9 & OAOS & 1509 & 1502 & isos \\
\hline 100.0 & 82.7 & 73.4 & 56.9 & 50.9 & 49.1 & 33.5 & 24.0 & 13.9 & 6.0 & 3.2 \\
\hline
\end{tabular}

percent relative survival af $48 \mathrm{~h}$

$\begin{array}{cccccc}\text { SP09 } & \text { SP02 } & \text { OA02 } & \text { SP05 } & \text { IS09 } & \begin{array}{c}\text { Sediment } \\ \text { Control }\end{array} \\ 3.2 & 3.3 & 3.6 & 3.9 & 4.0 & 4.8\end{array}$

OA09

$1505 \quad 1502$

CLAM REBURIAL

$\begin{array}{lllllllll}3.2 & 3.3 & 3.6 & 3.9 & 4.0 & 4.8 & 5.8 & 7.0 & 7.5\end{array}$

- ET50 (in min.)

COPEPOD REPRODUCTION

$\begin{array}{llllllllll}\begin{array}{l}\text { Seawater } \\ \text { Control }\end{array} & \text { SPOS } & \text { OA09 } & \text { OA05 } & \text { OA02 } & \text { SP02 } & \text { ISO5 } & \text { ISO2 } & \text { ISO9 } & \text { SP09 } \\ 181.0 & 121.2 & 118.8 & 113.9 & 112.0 & 107.5 & 103.8 & 96.9 & 84.0 & 62.9\end{array}$

o number of young produced per adult over 4 weeks

Fig. 2. Summary of bioassay results (mean values). Treatments not underlined by the same line are significantly different at $\mathrm{p}<0.05$ (1-tailed t-test) 
ences in survival occurred $(F=73.8, p=0.005)$. All samples except for SP05 had significantly $(p=0.05)$ lower survivals than the seawater and sediment controls.

Mean percent abnormal larvae ranged from a low of $5.6 \%$ in the controls to a high of $67.7 \%$ in sample IS02. Mean percent abnormal larvae in the controls were well below the maximum $10 \%$ criterion for seawater set by ASTM (1985b). Results of the analysis of variance indicated that significant differences in mussel larvae abnormalities occurred $(F=40.6, p=0.005)$. All Islais Waterway samples and samples OA05 and OA09 had significantly $(p=0.05)$ higher abnormalities than the controls.

Water quality parameters during testing were: temperature, 18 to $20.5^{\circ} \mathrm{C}$; salinity, 27 to $28 \mathrm{ppt}$; $\mathrm{pH}, 8.1$ to 8.4; DO, 4.8 to $7.0 \mathrm{mg} \mathrm{l}^{-1}$ (all Islais Waterway samples had DO values less than $5.5 \mathrm{mg} \mathrm{l}^{-1}$ ). These measurements are all within the water quality criteria set by ASTM (1985b) for bivalve larvae toxicity testing of seawater

\section{Clam reburial}

There were no clam mortalities in any of the test or control sediments over the $48 \mathrm{~h}$ exposure period. With 2 exceptions, mean reburial rates (ET50 values) showed the following trend: fastest in the San Pablo Bay site samples, slowest in the Islais Waterway site samples and intermediate in the Oakland site samples. However none of the differences between the test sediments were significantly $(p=0.05)$ different from the control. The results of the analysis of variance were $\mathrm{F}=2.44,0.025<\mathrm{p}<0.05$. This lack of statistical difference is attributable to the fact that one of the 5 control replicates had the slowest reburial time of any of the sediments tested (ET50 $=13.0 \mathrm{~min}$ ). In contrast the remaining 4 control replicates had some of the fastest reburial rates for any of the test groups (ET50s of 1.0 to $5.0 \mathrm{~min}$ ). If all of the control data had been ignored, then the reburial rates in samples IS02 and IS05 would have been significantly slower $(p=0.05)$ than the rates in all other samples tested except OA09, for which the reburial rate was indistinguishable.

Water quality parameters during testing were: temperature, 15 to $16.5^{\circ} \mathrm{C}$; salinity, 27 to $31 \mathrm{ppt}_{\text {; }} \mathrm{pH}, 8.0$ to 8.5; DO, greater than $4.7 \mathrm{mg} \mathrm{l}^{-1}$ except for sample ISO2 which had a DO value of $3.6 \mathrm{mg} \mathrm{l}^{-1}$.

\section{Harpacticoid copepod bioassay}

There were no morphological abnormalities observed in any of the test or control treatments over the 4 wk exposure period for the Tigriopus californicus reproductive success bioassays. None of the test sedi- ments prevented normal development from the nauplii to the more advanced copepodite form.

Compared to the other bioassays, the results of this testing were highly variable as exemplified by standard deviations of up to $50 \%$ of the means. Mean number of young produced per adult over $4 \mathrm{wk}$ ranged from 62.9 (SP09) to 181.0 (seawater control). The results of the analysis of variance indicated that some differences occurred in the number of young produced between the treatments $(F=1.88,0.05<p<0.1)$. Significantly lower numbers of young were produced ( $p=0.05$ ) by copepods exposed to samples of sediments from all 3 Islais Waterway stations and 2 San Pablo Bay stations compared to the seawater control.

Water quality parameters during testing were: temperature, 17 to $20^{\circ} \mathrm{C}$; salinity, 30 to $35 \mathrm{ppt}$; $\mathrm{pH}, 7.8$ to 8.5; DO. greater than $4.0 \mathrm{mg} \mathrm{l}^{-1}$ and generally greater than $4.5 \mathrm{mg} \mathrm{l}^{-1}$.

\section{Benthic infaunal analyses}

Taxonomic analyses

A total of 70 taxa were identified. Of these taxa, 36 were polychaete annelids, 10 were pelycepod molluscs, 5 were amphipod crustaceans, and 19 were additional taxa of 1 or 2 species of oligochaetes, turbellarians, sipunculids, ostracods, cumaceans, tanaids, decapods, brachyurans, pycnogonids, aeolid nudibranchs, ophiuroids, phoronids, and nemerteans. A complete list and classification for these taxa is provided in Chapman et al. (1986).

Comparative data on the abundances of the most dominant taxa from each of the 9 stations are provided in Table 3 . The combined abundances of these dominant taxa accounted for over $95 \%$ of the total individuals found in each station.

Differences (and similarities) in the occurrence of taxa among the sites were observed. For instance, the San Pablo Bay and Oakland sites had roughly similar faunal assemblages, whereas distinct faunal assemblages were found in the Islais Waterway site. The benthic tube-dwelling amphipod Ampelisca abdita was by far the most numerically dominant taxon at all Oakland and San Pablo Bay stations, but it was rare at the Islais Waterway site. The polychaete Streblospio benedicti and the bivalve mollusc Macoma nasuta were only found in Islais Waterway at Stn IS05.

Generally, the Oakland site was dominated by gammarid amphipods ( 3 of 5 dominants) with 1 or 2 polychaete taxa. The San Pablo Bay reference site was dominated by a single amphipod, Ampelisca abdita, but the other 4 dominant taxa were polychaetes. Total abundance was very low at the Islais Waterway site. This site was dominated by the polychaete Capitella 
Table 3 . The most abundant taxa present at each station

\begin{tabular}{|c|c|c|c|c|c|c|c|c|c|}
\hline \multirow[b]{2}{*}{ Taxa } & \multicolumn{3}{|c|}{ Oakland } & \multicolumn{3}{|c|}{ San Pablo Bay } & \multicolumn{3}{|c|}{ Islais Waterway } \\
\hline & $\mathrm{OA} 02$ & OA05 & OA09 & SP02 & SP05 & SP09 & ISO2 & IS05 & ISO9 \\
\hline Photis californica (C) & $19^{2}$ & 60 & 102 & + & & + & & & \\
\hline Leptochelia sp. (C) & 17 & + & 44 & & & & & & \\
\hline Phoronis sp. (Ph) & + & 84 & 18 & & 2 & + & & & \\
\hline Euchone analis $(\mathrm{Po})$ & 12 & 16 & + & + & + & + & & + & \\
\hline Harmothoe imbricata (Po) & 22 & 15 & 19 & + & 14 & 14 & + & & \\
\hline Ampelisca abdita (C) & 2882 & 3522 & 3402 & 575 & 337 & 806 & 1 & + & + \\
\hline Corophium sp. (C) & + & + & + & 52 & 2 & 13 & & & \\
\hline Asychis sp. (Po) & + & + & + & & 6 & 4 & & & \\
\hline Glycinde picta (Po) & + & + & + & 2 & 3 & 12 & & + & 4 \\
\hline Capitella capitata $(\mathrm{Po})$ & & + & & & & + & 46 & 58 & \\
\hline Macoma nasuta (M) & & & & & & & & & 2 \\
\hline Nephtys caecoides $(\mathrm{Po})$ & & & & & & + & & & 1 \\
\hline Streblospio benedicti (Po) & & & & & & & & & 1 \\
\hline Macoma expansa (M) & & + & + & & + & + & & & 1 \\
\hline Tubificoides brownae (O) & & & & & + & & & + & + \\
\hline Platyhelminthes & & + & & 1 & & + & & & \\
\hline \multicolumn{10}{|c|}{$\begin{array}{l}\text { Po = Polychaeta; } \mathrm{C}=\text { Crustacea; } \mathrm{M}=\text { Mollusca; } \mathrm{Ph}=\text { Phoronida; } \mathrm{O}=\text { Oligochaeta } \\
\text { a Truncated (non-decimal) mean abundance (no. of individuals) values per } 0.1 \mathrm{~m}^{2} ; \text { numerical abundances are only provided } \\
\text { for the } 5 \text { most abundant taxa whose abundance is also at least } 1 \text { ind } 0.1 \mathrm{~m}^{-2} ;+ \text { indicates occurrence at a station, but at mean } \\
\text { abundance values less than those for the } 5 \text { most abundant taxa and/or less than } 1 \text { ind } 0.1 \mathrm{~m}^{-2}\end{array}$} \\
\hline
\end{tabular}

capitata, with incidental occurrence of other polychaetes, oligochaetes and bivalve molluscs.

\section{Community descriptive analysis}

Table 4 provides the following community descriptive parameters for each of the stations and sites: number of taxa (=species richness, S), ShannonWeiner diversity index $(\mathrm{H})$, Pielou's equitability index (J), total sample abundance, and a measure of numerical dominance - the complement of equitability (I-J). Although examination of similar data for individual replicates (cf. Chapman et al. 1986) indicated that there was a relatively high degree of within-station

Table 4. Summary of infauna community descriptive parameters. S: number of taxa; H: Shannon-Wiener diversity; I-J: numerical dominance. Total abundance: numbers of individuals per $0.1 \mathrm{~m}^{2}$

\begin{tabular}{|c|c|c|c|c|c|c|c|c|c|}
\hline$\frac{\text { Site }}{\text { San Pablo Bay }}$ & $\begin{array}{c}\text { Station } \\
02\end{array}$ & \multicolumn{2}{|r|}{$\mathrm{S}$} & \multicolumn{2}{|c|}{$\mathrm{H}$} & \multicolumn{2}{|c|}{ I-J } & \multicolumn{2}{|c|}{ Total abundance } \\
\hline San Pablo Bay & $\begin{array}{l}02 \\
05 \\
09\end{array}$ & $\begin{array}{r}6.6 \\
9.8 \\
14.4\end{array}$ & $\begin{array}{l}(0.98)^{b} \\
(0.80) \\
(1.08)\end{array}$ & $\begin{array}{l}0.21 \\
0.24 \\
0.19\end{array}$ & $\begin{array}{l}(0.05) \\
(0.03) \\
(0.03)\end{array}$ & $\begin{array}{l}0.68 \\
0.75 \\
0.84\end{array}$ & $\begin{array}{l}(0.12) \\
(0.04) \\
(0.02)\end{array}$ & $\begin{array}{l}637 \\
374 \\
816\end{array}$ & $\begin{array}{r}(215.1) \\
(96.3) \\
(122.6)\end{array}$ \\
\hline Oakland & $\begin{array}{l}02 \\
05 \\
09\end{array}$ & $\begin{array}{l}12.6 \\
14.2 \\
16.6\end{array}$ & $\begin{array}{l}(1.57) \\
(1.88) \\
(1.32)\end{array}$ & $\begin{array}{l}0.13 \\
0.17 \\
0.19\end{array}$ & $\begin{array}{l}(0.02) \\
(0.04) \\
(0.02)\end{array}$ & $\begin{array}{l}0.88 \\
0.85 \\
0.85\end{array}$ & $\begin{array}{l}(0.01) \\
(0.03) \\
(0.01)\end{array}$ & $\begin{array}{l}3024 \\
3788 \\
3694\end{array}$ & $\begin{array}{l}(879.9) \\
(480.9) \\
(231.5)\end{array}$ \\
\hline Islais Waterway & $\begin{array}{l}02 \\
05 \\
09\end{array}$ & $\begin{array}{l}2.4 \\
2.0 \\
8.2\end{array}$ & $\begin{array}{l}(0.40) \\
(0.32) \\
(0.86)\end{array}$ & $\begin{array}{l}0.08 \\
0.06 \\
0.83\end{array}$ & $\begin{array}{l}(0.04) \\
(0.02) \\
(0.51)\end{array}$ & $\begin{array}{l}0.62 \\
0.65 \\
0.08\end{array}$ & $\begin{array}{l}(0.17) \\
(0.17) \\
(0.03)\end{array}$ & $\begin{array}{l}47 \\
59 \\
15\end{array}$ & $\begin{array}{r}(17.7) \\
(16.8) \\
(2.8)\end{array}$ \\
\hline $\begin{array}{l}\text { San Pablo Bay } \\
\text { Overall }^{\lrcorner}\end{array}$ & & 10.3 & $(1.00)$ & 0.21 & $(0.02)$ & 0.76 & $(0.04)$ & 609 & $(95.2)$ \\
\hline $\begin{array}{l}\text { Oakland } \\
\text { Overall } \\
\text { Islais Waterway }\end{array}$ & & 14.5 & $(0.97)$ & 0.17 & $(0.02)$ & 0.86 & $(0.01)$ & 3502 & $(330.3)$ \\
\hline $\begin{array}{l}\text { Overall }^{d} \\
\text { Data from all re } \\
\text { b Values represe }\end{array}$ & $\begin{array}{l}\text { abs from } \\
\text { with sam }\end{array}$ & $\begin{array}{l}\text { were } \\
\text { bracl }\end{array}$ & $\begin{array}{l}(0.82) \\
\text { used for } \\
\text { kets }(n=\end{array}$ & 0.33 & $\begin{array}{l}(0.10) \\
5(n=15\end{array}$ & 0.45 & $(0.10)$ & 41 & (9.1) \\
\hline
\end{tabular}




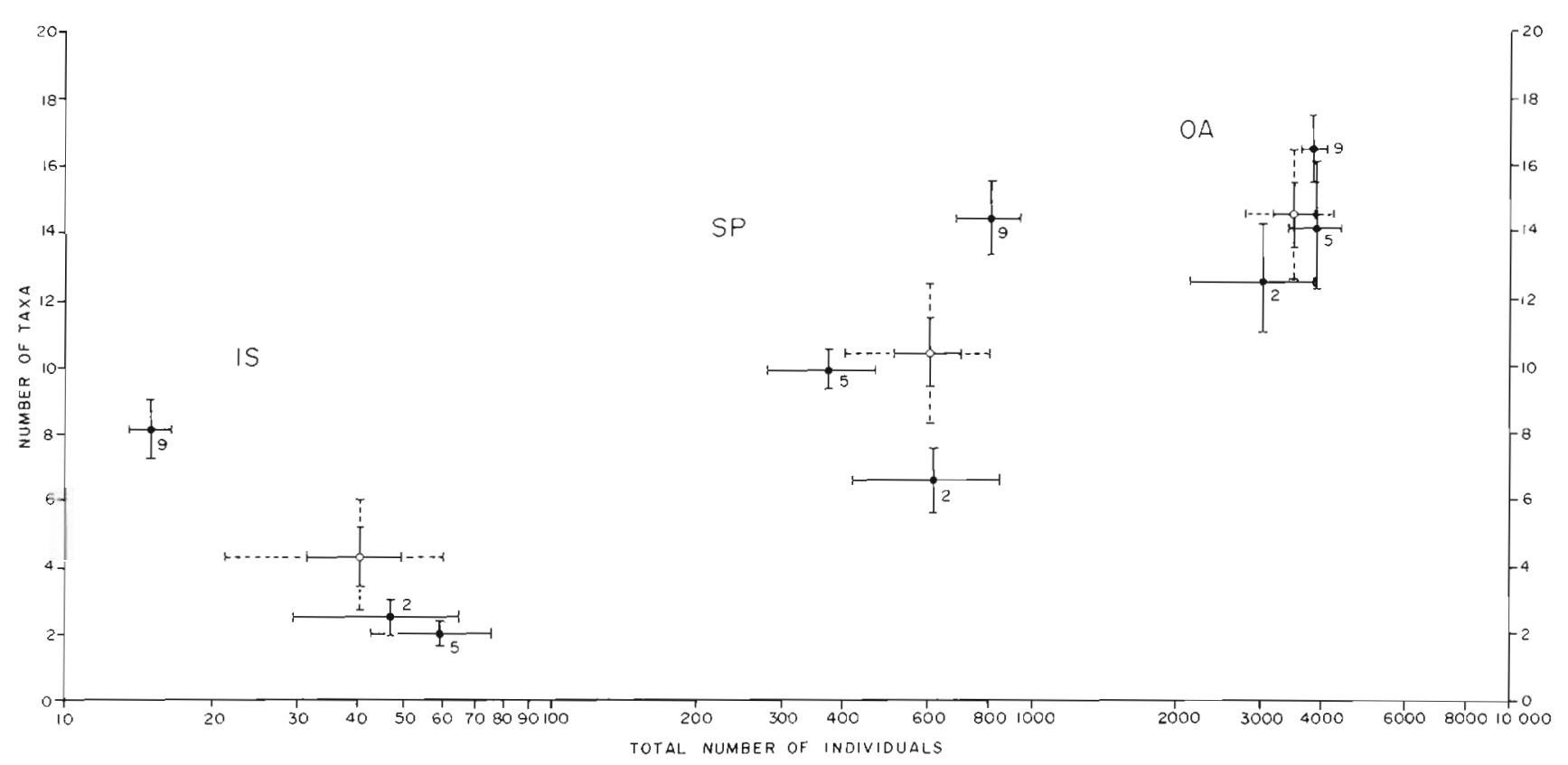

Fig. 3. Mean taxa richness plotted against mean total abundance. Solid bars represent standard errors. Extended (dashed) bars represent $95 \%$ confidence limits for sites. Solid circles are individual stations $(n=5)$; open circles are sites $(n=15)$

variability associated with each of these parameters, between-site differences were quite apparent, with Islais Waterway stations generally having very low species richness and total numbers of individuals while the San Pablo Bay and Oakland sites showed progressively greater values for these variables.

Of the 3 Islais Waterway stations, IS09 was anomalous: it had the highest species richness, the highest sample diversity and the lowest dominance. Species diversity was higher than at any of the other stations by a factor of approximately 4 .

The Oakland and San Pablo Bay sites both had very high mean numerical dominance values and high total sample abundances. Large numbers of the amphipod Ampelisca abdita within these sites, but not within the Islais Waterway site, accounted for the observed differences in diversity. Highest mean diversity occurred at the Islais Waterway site, solely as a result of the anomalously high values for Stn ISO9.

Fig. 3 illustrates the relationship between species richness and total abundance for each station and for each site. This figure demonstrates the high degree of variability among stations at any one of the study sites. Stn IS09 is once again shown as anomalous compared to IS02 and IS05. Although the low total number of individuals found at ISO9 was characteristic of the Islais Waterway site, species richness was much higher there than at the other 2 IS stations, and was not significantly different $(p=0.05)$ than for the San Pablo Bay stations.

\section{Proportions of major taxonomic groups}

The mean proportions of major taxonomic groups are compared between stations and between sites in Fig. 4 . Gammarid amphipods represented the dominant group within both of the Oakland and San Pablo Bay sites with one species, Ampelisca abdita, comprising over $98 \%$ of the amphipods present at both sites.

The Islais Waterway site had a mean amphipod component of less than $5 \%$ of the total sample abundance. In contrast, whereas the polychaetes constituted less than $7 \%$ of the total fauna in the Oakland and San Pablo Bay sites, this taxonomic group comprised over $80 \%$ of the total abundance within the Islais Waterway site. This group was dominated by a single species, Capitella capitata, which comprised over $95 \%$ of the polychaetes present. Table 5 documents the numerical differences between Ampelisca abdita and C. capitata for the 3 sites.

Although the Islais Waterway site had significantly $(p=0.05)$ greater numbers of Capitella capitata than any other site, this value would have been even higher were it not for Stn IS09 which had no C. capitata. Other stations within this site, IS05 for example, had replicate $0.1 \mathrm{~m}^{2}$ grabs containing in excess of 100 of these animals.

\section{Cluster analyses}

Cluster analyses (Fig. 5) indicated a high degree of benthic infaunal similarity between samples collected 

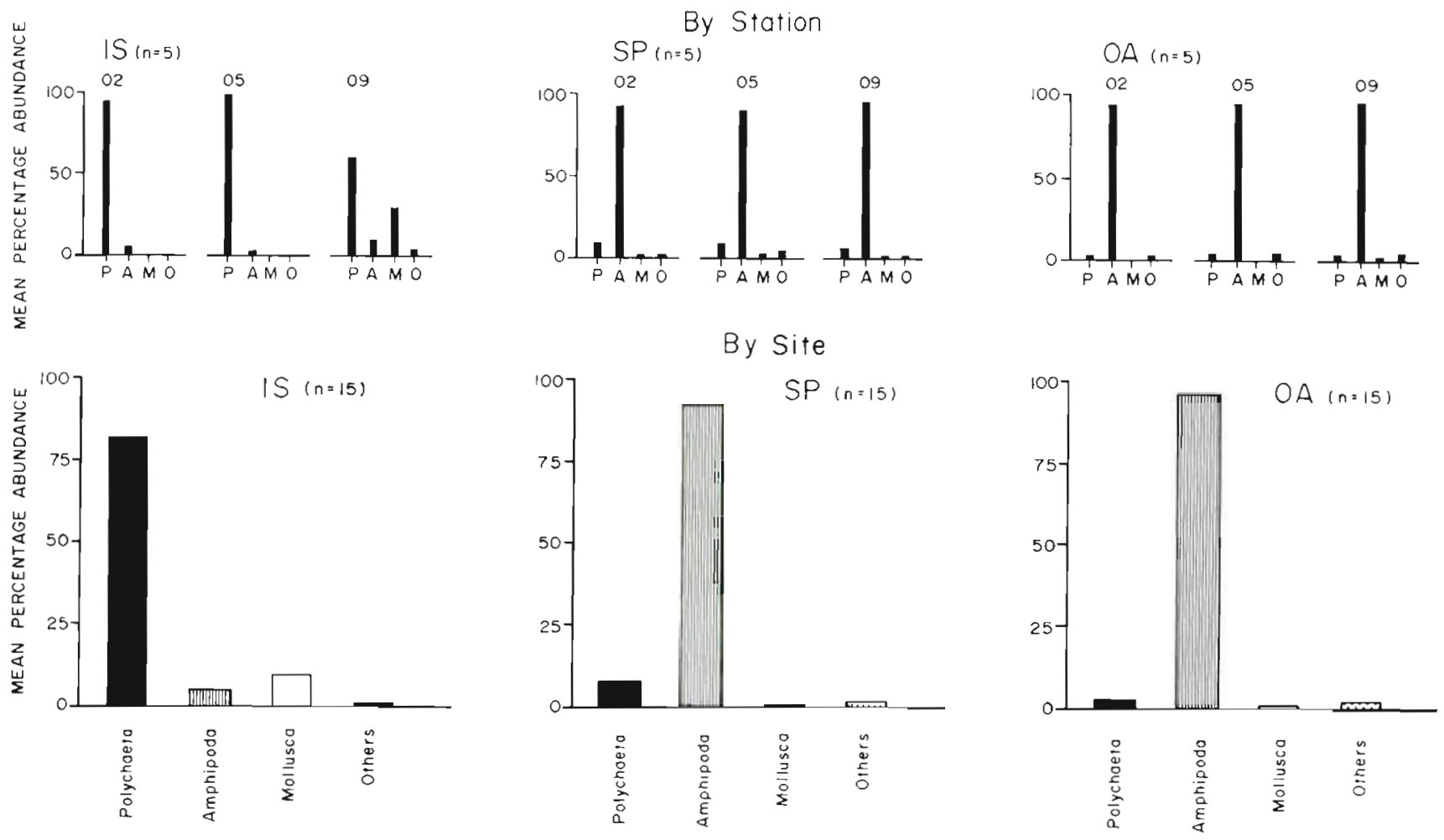

Fig. 4. Percent of total abundance represented by each major taxa present at each station and at each site

Table 5. Ampelisca abdita and Capitella capitata. Mean abundances (SE) at the 3 sites $(n=15)$

\begin{tabular}{|lrrrr|}
\hline \multicolumn{4}{c|}{ Mean no. per grab $\left(0.1 \mathrm{~m}^{2}\right)$} \\
Site & Ampelisca abdita & Capitella capitata \\
\hline OA & 3269.2 & $(320.9)$ & 3.20 & $(1.71)$ \\
SP & 573.3 & $(94.3)$ & 0.13 & $(0.10)$ \\
IS & 0.7 & $(0.2)$ & 34.53 & $(10.06)$ \\
\hline
\end{tabular}

at stations within the Oakland and San Pablo Bay sites. All Oakland stations clustered together, with an overall similarity of $80 \%$. Stations within San Pablo Bay showed a similar affinity, with between-station simi-

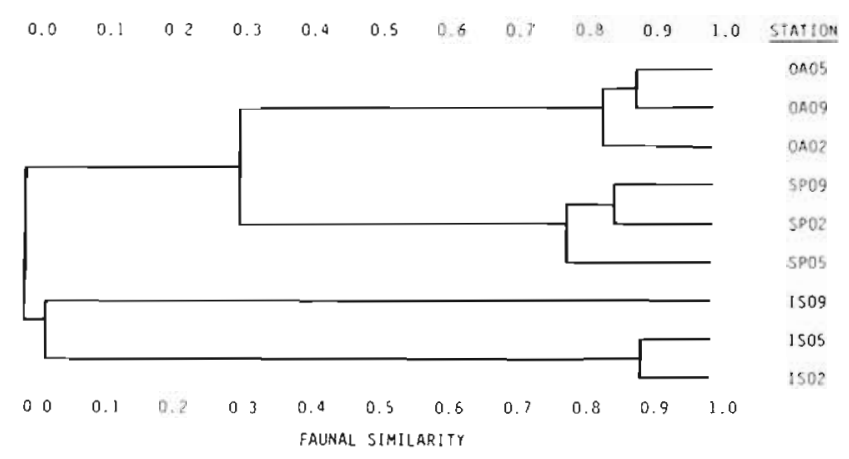

Fig. 5. Results of between-station cluster analysis. Similarities based on sample means $(n=5)$ larity of at least $77 \%$. Islais Waterway stations, however, did not show the same high similarities. Although Stns ISO2 and ISO5 had a similarity of $90 \%$ : Stn IS09 had a similarity level of 0 to $6 \%$ with Stns ISO2 and IS05, respectively.

Fig. 5 also shows that Oakland stations are much more similar to San Pablo Bay than to the Islais Waterway stations. Islais Waterway stations had a similarity with all of the other stations of less than $3 \%$ when the results of the same cluster analyses were performed for pooled between-site species abundance data. Trends observed for the between-station analysis were duplicated.

\section{DISCUSSION}

\section{Sediment physical and chemical characteristics}

The relative degree that the chemical concentrations in the sediments were elevated above the mean reference concentrations (RTR) at the San Pablo Bay site was used as the criterion for selecting the chemicals most likely to be anthropogenically enriched and of concern. Those chemical elements and compounds that were consistently detected in San Francisco Bay and which are considered likely to be responsive to anthropogenic loading are summarized in Table 6 for 
Table 6. Ratio-to-Reference values for all stations and sites based on TOC-normalized sediment chemistry data. (Chemical concentrations for each substance divided by mean values for the San Pablo Bay reference site)

\begin{tabular}{|c|c|c|c|c|c|c|c|c|c|c|c|c|c|c|c|}
\hline \multirow[b]{2}{*}{ Site } & \multirow[b]{2}{*}{ Station } & \multicolumn{14}{|c|}{ Ratio-to-Reference (RTR) values } \\
\hline & & As & $\mathrm{Cr}$ & $\mathrm{Cu}$ & $\mathrm{Pb}$ & $\mathrm{Hg}$ & $\mathrm{Ag}$ & $\mathrm{Sn}$ & $\mathrm{Zn}$ & LPAH & HPAH & $\begin{array}{c}\text { Copros- } \\
\text { tanol }\end{array}$ & DDTs & PCBs & $\begin{array}{c}\text { Aggre- } \\
\text { gate } \\
\text { index }\end{array}$ \\
\hline San Pablo & 02 & 1.34 & 1.43 & 1.20 & 1.41 & 0.81 & 1.29 & 1.21 & 1.40 & 0.42 & 0.74 & 0.67 & 1.15 & 0.94 & 0.86 \\
\hline \multirow{4}{*}{ Bay } & 05 & 0.79 & 0.82 & 0.94 & 0.79 & 1.04 & 0.76 & 1.04 & 0.84 & 1.35 & 1.34 & 1.05 & 1.05 & 0.88 & 1.09 \\
\hline & 09 & 0.87 & 0.76 & 0.87 & 0.80 & 1.15 & 0.95 & 0.75 & 0.76 & 1.23 & 0.92 & 1.28 & 0.80 & 1.18 & 1.05 \\
\hline & Mean & 1.00 & 1.00 & 1.00 & 1.00 & 1.00 & 1.00 & 1.00 & 1.00 & 1.00 & 1.00 & 1.00 & 1.00 & 1.00 & 1.00 \\
\hline & SD & 0.24 & 0.30 & 0.14 & 0.29 & 0.14 & 0.22 & 0.19 & 0.28 & 0.42 & 0.25 & 0.25 & 0.15 & 0.13 & 0.10 \\
\hline \multirow[t]{5}{*}{ Oakland } & 02 & 0.89 & 0.86 & 0.93 & 1.18 & 1.16 & 1.32 & 0.98 & 0.91 & 2.65 & 2.86 & 1.58 & 1.92 & 2.78 & 2.14 \\
\hline & 05 & 0.96 & 0.92 & 0.93 & 1.24 & 1.03 & 1.33 & 1.19 & 0.91 & 2.91 & 2.75 & 3.20 & 1.58 & 2.39 & 2.32 \\
\hline & 09 & 0.72 & 0.86 & 0.87 & 1.14 & 1.27 & 1.67 & 1.27 & 0.86 & 2.09 & 1.78 & 0.56 & 1.15 & 2.15 & 1.47 \\
\hline & Mean & 0.86 & 0.88 & 0.91 & 1.18 & 1.15 & 1.44 & 1.14 & 0.89 & 2.55 & 2.46 & 1.78 & 1.55 & 2.44 & 1.97 \\
\hline & $\mathrm{SD}$ & 0.10 & 0.03 & 0.03 & 0.04 & 0.09 & 0.16 & 0.12 & 0.02 & 0.34 & 0.49 & 1.09 & 0.31 & 0.26 & 0.37 \\
\hline Islais & 02 & 0.26 & 0.40 & 0.77 & 2.60 & 0.77 & 1.73 & 1.02 & 0.78 & 6.30 & 5.94 & 19.45 & 1.19 & 4.41 & 6.39 \\
\hline \multirow[t]{4}{*}{ Waterway } & 05 & 0.38 & 0.55 & 0.75 & 1.72 & 2.07 & 2.36 & 1.16 & 0.70 & 7.06 & 7.47 & 20.66 & 1.88 & 8.03 & 7.72 \\
\hline & 09 & 0.91 & 0.91 & 1.13 & 1.60 & 1.39 & 2.40 & 1.34 & 1.06 & 5.14 & 6.17 & 9.40 & 2.56 & 3.93 & 4.76 \\
\hline & Mean & 0.52 & 0.62 & 0.88 & 1.97 & 1.41 & 2.17 & 1.17 & 0.85 & 6.17 & 6.52 & 16.50 & 1.88 & 5.45 & 6.29 \\
\hline & $\mathrm{SD}$ & 0.28 & 0.21 & 0.17 & 0.45 & 0.53 & 0.30 & 0.13 & 0.15 & 0.79 & 0.67 & 5.04 & 0.56 & 1.83 & 1.21 \\
\hline
\end{tabular}

TOC-normalized data. This table includes 8 trace metals and 5 groups of organic compounds.

These data were used to generate an aggregate contamination index by averaging all of the trace elements to a single value prior to averaging this value with the individual values for the organic compounds. The index value is the mean of combined values for 5 chemical groups and coprostanol and represents one attempt, based on our experience in reviewing contamination data, to achieve a single composite value that will identify contaminated sites. Because background levels of metals are substantial and metals are not as useful as organics for discriminating marine pollution (Quinlan et al. 1985), the weighting of metals data is reduced relative to the organics. There is a trend of increasing index values from the San Pablo Bay site to the Oakland site to the Islais Waterway site.

Sediment chemistry data for San Francisco Bay are compared to similar data from 2 other areas of the West Coast (Southern California Bight and Puget Sound) in Table 7 . These data were selected from available information for these 2 areas since they have been extensively sampled for comprehensive chemical analyses. Data are presented for the chemical concentrations observed in sites away from urban influences (reference sites) and the maximum concentrations in surface sediments (upper few $\mathrm{cm}$ ) found in contaminated sites.
The maximum concentrations for most of the substances at the Islais Waterway site were much lower than the levels observed in contaminated sites in either Southern California or Puget Sound (Table 7). These data also indicate that the concentrations of most chemicals in the San Francisco Bay reference site (SP) may be equal to or slightly higher than those observed in reference sites off Southern California and in Puget Sound. This enrichment may reflect regional differences in the natural levels of the chemicals, the effects of grain size/TOC differences among the reference sites, and/or actual differences in the levels of anthropogenic contamination. These data also demonstrate the difficulty of using chemical data alone to define 'problem areas', While the Islais Waterway site certainly stands out as the most contaminated of the 3 sites in San Francisco Bay, none of these sites were particularly enriched when compared to 2 other areas of the West Coast. Under this wider perspective, then, it would be difficult to say, given just the chemical data, that the San Francisco Bay data indicate that a problem (i.e. pollution-induced degradation) exists. However, the concentrations of some of the substances measured in Islais Waterway sediments were close to or exceeded the concentrations at which biological effects have been observed in studies performed in Puget Sound (Tetra Tech 1985, Chapman 1986). 
Table 8. Ratios between mean values for the reference site (SP) and individual station values for all sediment bioassays

\begin{tabular}{|c|c|c|c|c|c|c|c|c|c|c|c|c|c|c|}
\hline \multirow[t]{3}{*}{ Site } & \multirow[t]{3}{*}{ Station } & \multicolumn{4}{|c|}{ Amphipod } & \multicolumn{4}{|c|}{ Mussel larvae } & \multicolumn{2}{|c|}{ Clam } & \multicolumn{2}{|c|}{ Copepod } & \multirow{3}{*}{$\begin{array}{c}\text { Mean } \\
\text { RTR } \\
\text { values }^{c}\end{array}$} \\
\hline & & \multicolumn{2}{|c|}{$\begin{array}{l}\text { Mean } \\
\text { mortality }\end{array}$} & \multicolumn{2}{|c|}{$\begin{array}{c}\text { Mean } \\
\text { emergence }\end{array}$} & \multicolumn{2}{|c|}{$\begin{array}{l}\text { Mean } \\
\text { normality }\end{array}$} & \multicolumn{2}{|c|}{$\begin{array}{l}\text { Mean } \\
\text { mortality }\end{array}$} & \multirow[t]{2}{*}{$\begin{array}{l}\text { ET } 50 \\
\text { (min) }\end{array}$} & \multirow[t]{2}{*}{ RTR } & \multirow{2}{*}{$\begin{array}{l}200 \text { minus } \\
\text { \# of young } \\
\text { produced }^{b}\end{array}$} & \multirow[t]{2}{*}{ RTR } & \\
\hline & & $\begin{array}{l}\text { No. } \\
\text { dead }\end{array}$ & $\mathrm{RTR}^{\mathrm{a}}$ & $\begin{array}{c}\text { No. } \\
\text { emerged }\end{array}$ & RTR & $\begin{array}{l}\% \text { ab- } \\
\text { normal }\end{array}$ & RTR & $\begin{array}{c}\% \\
\text { dead }\end{array}$ & RTR & & & & & \\
\hline \multirow[t]{3}{*}{ SP } & 02 & 1.8 & 0.7 & 1.1 & 1.6 & 13.4 & 1.1 & 43.1 & 1.2 & 3.3 & 0.9 & 92.5 & 0.9 & 1.1 \\
\hline & 05 & 0.8 & 0.3 & 0.5 & 0.7 & 7.7 & 0.6 & 17.3 & 0.5 & 3.9 & 1.1 & 78.8 & 0.8 & 0.7 \\
\hline & 09 & 4.8 & 1.9 & 0.5 & 0.7 & 15.3 & 1.3 & 49.1 & 1.3 & 3.2 & 0.9 & 137.1 & 1.3 & 1.2 \\
\hline \multicolumn{2}{|c|}{ Overall $(n=3)^{d}$} & 2.5 & 1.0 & 0.7 & 1.0 & 12.1 & 1.0 & 36.5 & 1.0 & 3.5 & 1.0 & 102.8 & 1.0 & 1.0 \\
\hline \multirow[t]{3}{*}{ OA } & 02 & 1.8 & 0.7 & 0.7 & 1.0 & 14.5 & 1.2 & 50.9 & 1.4 & 3.6 & 1.0 & 88.6 & 0.9 & 1.0 \\
\hline & 05 & 2.6 & 1.0 & 0.4 & 0.6 & 24.7 & 2.0 & 76.0 & 2.1 & 3.9 & 1.1 & 86.1 & 0.8 & 1.3 \\
\hline & 09 & 2.6 & 1.0 & 1.9 & 2.7 & 18.7 & 1.5 & 66.5 & 1.8 & 5.8 & 1.7 & 81.2 & 0.8 & 1.6 \\
\hline \multicolumn{2}{|c|}{ Overall $(\mathrm{n}=3)$} & 2.3 & 0.9 & 1.0 & 1.4 & 19.3 & 1.6 & 64.5 & 1.8 & 4.4 & 1.3 & 85.1 & 0.8 & 1.3 \\
\hline \multirow[t]{3}{*}{ IS } & 02 & 19.0 & 7.6 & 7.4 & 10.6 & 67.7 & 5.6 & 94.0 & 2.6 & 7.5 & 2.1 & 103.1 & 1.0 & 4.9 \\
\hline & 05 & 4.8 & 1.9 & 1.7 & 2.4 & 65.9 & 5.4 & 96.8 & 2.7 & 7.0 & 2.1 & 96.2 & 0.9 & 2.6 \\
\hline & 09 & 7.4 & 3.0 & 0.6 & 0.9 & 31.9 & 2.6 & 86.1 & 2.4 & 4.0 & 1.1 & 116.0 & 1.1 & 1.8 \\
\hline \multicolumn{2}{|c|}{ Overall $(n=3)$} & 10.4 & 4.2 & 3.2 & 4.6 & 55.2 & 4.6 & 92.3 & 2.5 & 6.2 & 1.8 & 104.7 & 1.0 & 3.1 \\
\hline \multicolumn{15}{|c|}{ a RTR: Ratio-to-Reference } \\
\hline \multicolumn{15}{|c|}{$\begin{array}{l}\text { b Arbitrary calculation used to adjust data for number of young produced per adult over } 4 \text { wk in order to calculate RTR values } \\
\text { in a similar format to other bioassay responses }\end{array}$} \\
\hline
\end{tabular}

The reason(s) for the difference between the results of the copepod test and the results of the other 3 bioassays is unknown, but may reflect a differential sensitivity to particular chemical contaminants. It is also possible that the organisms are reacting to nonchemical factors such as sediment texture or Eh.

RTR values are derived in Table 8 for all sediment bioassays. Based upon mean RTR values calculated per site, the Islais Waterway site was more toxic than Oakland, while Oakland was slightly more toxic than San Pablo Bay. IS02 was the most toxic station.

Unlike the sediment chemistry data, it is not possible to quantitatively compare the San Francisco Bay sediment bioassay data with similar data for other West Coast areas. Comparisons are best done in terms of relative percentages of toxic responses at a site (number of stations toxic divided by total number of stations tested). In Puget Sound, from 0 to $32 \%$ of the sediment samples from reference sites have shown significant lethal responses with the amphipod sediment bioassay while up to $80 \%$ of the samples from highly polluted sites have shown lethal responses (Long 1985). In the present study the amphipod bioassay gave between 0 and $10 \%$ lethal responses at the Oakland and San Pablo Bay sites, respectively, indicating that these sites have toxicity similar to Puget Sound reference sites. However, at the Islais Waterway site a total of $80 \%$ lethal responses $(8$ stations of 10 tested) were recorded, indicating that this site had similar toxicity to the most toxic Puget Sound sites.

\section{Benthic infauna}

The assemblage of marine infauna collected during this study was dominated by polychaete annelids and tube-dwelling amphipods. The taxa identified during this study were generally similar to those previously identified from San Francisco Bay (Nichols 1979, 1985, CH2M-Hill 1979). In a summary of the history of benthic community studies in the Bay, Liu et al. (1975) reported that generally 10 to 30 taxa are encountered per station, similar to the taxa richness observed in the present study, in which a total of 70 benthic infaunal taxa were identified from 45 grab samples taken at 9 stations and 3 sites in San Francisco Bay. At any one station taxa richness ranged from 5 to a maximum of 35 taxa. Taxa richness at any one site ranged from 20 to a maximum of 43 taxa. Each site was dominated by one of 2 taxa, Ampelisca abdita or Capitella capitata.

The following 4 indices were used to summarize the benthic infaunal data: taxa richness; total abundance; relative abundance of major taxa (Amphipoda, Polychaeta, Mollusca); numerical dominance. Taxa richness (number of taxa) and total abundance (number of individuals) are commonly reported variables, and have been used extensively to evaluate 
pollution effects (cf. Pearson \& Rosenberg 1978). Pristine sites typically have high taxa richness and total abundance. Power analyses have shown that taxa richness is a precise measure of community change relative to other benthic variables, and is an efficient tool with which to evaluate community responses to pollution (Tetra Tech 1985). Total abundance generally exhibits more within-station variability than does taxa richness, and is therefore a relatively less powerful statistical measure. But changes in total abundances do occur in response to pollutant stresses (Pearson \& Rosenberg 1978) and can be tested statistically. The relative abundance of major taxa was included to facilitate the identification of problem sites. This analysis assessed major taxonomic groups considered to be sensitive to pollution (e.g. amphipods) and those considered more tolerant (e.g. polychaetes and molluscs). Amphipods are among the infaunal groups most sensitive to environmental degradation (BellanSantini 1980). Chapman et al. (1985) and Long \& Chapman (1985) have shown a correspondence between depressed amphipod abundances, elevated polychaete and mollusc abundances, and sediment toxicity on a site-site basis, but not necessarily on a station-station basis. Dominance was calculated as the complement of equitability. This index provides useful information on the dispersion of individuals among the species in a benthic community.

These parameters were used in Table 9 to obtain Ratio-to-Reference values for each station and site. Each parameter was given equal weight to provide an additive numerical 'description' of site conditions relative to the reference conditions. On this basis, all Oakland stations were slightly less altered from background conditions than the San Pablo Bay stations. All Islais Waterway stations were more altered.
Stn IS09 had the highest mean value $(54 \times$ reference), due to the high percentage of Mollusca found at this station compared to the reference. Overall, the benthos at the Islais Waterway site were almost $25 \times$ more altered than those at the San Pablo Bay site, while the benthos at the Oakland site were slightly less altered than those at the San Pablo Bay site.

On the basis of the above 4 parameters, Islais Waterway was the most degraded site. It was the most depauperate, in terms of taxa richness and total abundance, of the 3 sites sampled. The fauna were dominated by polychaete annelids, and amphipods were rare. However, within-site variability was high, with Stn IS09 differing greatly from ISO2 and IS05. Stns ISO2 and IS05 had 45 to 60 individuals distributed over 2 to 3 taxa; however Stn IS09 had fewer individuals and 4 times the number of taxa. Stn ISO9 was the only station in Islais Waterway that did not include the 'indicator' polychaete Capitella capitata. These differences between the infauna at Stn ISO9 as compared to the other 2 Islais Waterway stations may be due to a number of factors including grain size differences in the sediments. They could also be due to a lower level of organic enrichment at Stn IS09.

The reference site, San Pablo Bay, had a mean of 10 taxa, with an average of 600 individuals in each grab sample $\left(0.1 \mathrm{~m}^{2}\right)$. Dominance was high at this site due to the presence of the tube-dwelling amphipod Ampelisca abdita, which contributed over $90 \%$ of the total number of individuals. A few speries of polychaetes were found in this site, while molluscs were virtually absent.

The Oakland site had a mean of 14 taxa, with an average of 3500 individuals in each grab sample. But this site also had the highest degree of numerical dominance of the 3 sites sampled. Ampelisca abdita

Table 9. Ratios between mean reference site (SP) values and individual station and site values based on benthic infauna data

\begin{tabular}{|c|c|c|c|c|c|c|c|c|c|c|c|c|}
\hline \multirow[t]{3}{*}{ Parameter } & \multicolumn{12}{|c|}{ Ratio-to-Reference ${ }^{a}$} \\
\hline & \multicolumn{4}{|c|}{ San Pablo Bay } & \multicolumn{4}{|c|}{ Oakland } & \multicolumn{4}{|c|}{ Islais Waterway } \\
\hline & 02 & 05 & 09 & Mean & 02 & 05 & 09 & Mean & 02 & 05 & 09 & Mean \\
\hline $1 /$ taxa richness $^{\mathrm{b}}$ & 1.56 & 1.05 & 0.71 & 1.0 & 0.81 & 0.78 & 0.62 & 0.71 & 4.35 & 5.26 & 1.25 & 4.76 \\
\hline $1 /$ total abundance $^{\mathrm{b}}$ & 0.95 & 1.64 & 0.75 & 1.0 & 0.20 & 0.16 & 0.16 & 0.17 & 12.50 & 10.00 & 50.00 & 11.11 \\
\hline Numerical dominance & 0.90 & 0.99 & 1.10 & 1.0 & 1.16 & 1.12 & 1.12 & 1.14 & 0.81 & 0.84 & 0.10 & 0.83 \\
\hline $1 / \%$ Amphipoda $^{\mathrm{b}}$ & 1.00 & 0.03 & 0.97 & 1.0 & 0.95 & 0.97 & 0.95 & 0.96 & 2.63 & 5.88 & 10.53 & 33.33 \\
\hline$\%$ Polychaeta & 1.04 & 1.22 & 0.74 & 1.0 & 0.35 & 0.26 & 0.23 & 0.28 & 14.29 & 14.29 & 8.33 & 14.29 \\
\hline$\%$ Mollusca & $\underline{0.67}$ & $\underline{2.00}$ & 0.33 & $\underline{1.0}$ & 0.00 & $\underline{1.00}$ & 0.83 & $\underline{0.58}$ & 0.00 & $\underline{0.00}$ & $\underline{254.33}$ & 84.75 \\
\hline Sum: & 6.12 & 7.93 & 4.6 & 6.0 & 3.47 & 4.29 & 3.91 & 3.84 & 34.58 & 36.27 & 324.54 & 149.07 \\
\hline Mean': & 1.02 & 1.32 & 0.77 & 1.0 & 0.58 & 0.71 & 0.65 & 0.64 & 5.76 & 6.04 & 54.09 & 24.85 \\
\hline \multicolumn{13}{|c|}{$\begin{array}{l}\text { a Reference = mean San Pablo Bay site values } \\
{ }^{b} \text { High values = least altered, thus these data are entered as reciprocals } \\
\text { ' Relative degree of alteration compared to mean reference values. Values greater than } 1.0 \text { indicate greater alteration, values } \\
\text { less than } 1.0 \text { indicate less alteration }\end{array}$} \\
\hline
\end{tabular}


was again dominant. In Norwegian fjords Ampelisca spp. have been classified as generally 'very tolerant' to pollution (Rygg 1985). The fauna are dominated by deposit and/or suspension feeders, and exhibit an increased abundance of 'opportunistic' taxa in conjunction with a decrease of other taxa representing a wide range of functional groups (e.g. sediment processors, carnivores). The reference site, San Pablo Bay, was similar in taxon composition. This type of taxon distribution is considered indicative of organic pollution (Pearson \& Rosenberg 1978).

In addition to pollution, biotic factors (e.g. competition, predation) can influence benthic infaunal community structure. These factors become important considerations when sediment parameters are considered along with the benthic infaunal data. If only the benthic infaunal data were considered, organic pollution would be suspected. However, TOC and TVS data for these 2 sites are within the normal estuarine range of values and do not suggest a high level of organic enrichment. It is possible that competitive exclusion by Ampelisca abdita, the dominant organism at the Oakland and San Pablo Bay sites, served to limit diversity, resulting in a dominated faunal assemblage indicative of some forms of organic pollution, but not necessarily a result of this condition. Dominance of the benthic infauna by tube-building $A$. abdita results in changes to the sediments including decreased median grain size, and can also result in an overall decreased species richness (Mills 1969). A. abdita may be responding opportunistically to particular conditions in San Francisco Bay (e.g. high clay, marginal organic matter, high currents).

Two major physical factors can also greatly influence benthic infaunal community structure: sediment grain size and depth (Nichols 1979). We attempted to collect the same type of sediment from the same depth at each sampling station. However, although water depths were kept relatively constant ( 6 to $12 \mathrm{~m}$ ), there were some differences in sediment texture among the sites. The San Pablo Bay sediments consisted, on average, of almost equal measures of sand, silt and clay. In comparison, Oakland sediments had substantially less sand and more clay; Islais Waterway sediments were predominantly silt. As previously discussed, Islais Waterway benthic fauna differed from those of the other 2 sites. The Oakland site and the San Pablo Bay site infauna also differed from each other, but were much more similar to each other than to the Islais Waterway site benthic fauna. These levels of faunal differences approximate the levels of grain size differences between the sites, and may in themselves account for the observed faunal differences between the sites, irrespective of sediment chemical contaminants.

\section{Sediment Quality Triad}

The relative information provided by each component of the Sediment Quality Triad related to a measure of pollution-induced degradation is summarized below:

\begin{tabular}{llll} 
Parameter & \multicolumn{2}{c}{ Measurement } & Measurement \\
\hline Bulk chemistry & $\rightarrow$ Contamination & Sediment & $\begin{array}{l}\text { Pollution- } \\
\text { Sediment bioassay } \rightarrow \text { Toxicity }\end{array}$ \\
Benthic infauna $\rightarrow$ Alteration & & $\begin{array}{l}\text { Quality } \\
\text { Triad }\end{array}$ & degradation \\
degrad
\end{tabular}

The Sediment Quality Triad can be used to determine pollution-induced degradation both areally and temporally for a large number of sites (and/or stations) by generating indices that represent individual aggregate characterizations of the respective chemistry, bioassay and benthic data. In this study we used the RTRs calculated in Tables 6,8 and 9 to illustrate the Triad of measures per station and per site. These RTR values were then plotted on scales with a common origin and placed at $120^{\circ}$ from each other to form triaxial plots (Fig. $6 \&$ 7). The area of the triangles was calculated for each of the stations at each of the 3 sites to estimate the relative degradation of the sites as well as to visually define the characteristics of 'background or reference stations (Fig. 6). Similar calculations were also done for the means of the 3 sites (Fig. 7).

Five stations (SP02, SP05, SP09, OA02, OA05) were the least pollution-degraded. Although the infauna were modified at these stations, the lack of elevated chemistry and low toxicity in the bioassay tests indicated that this was not a result of measured chemicals.

Two stations (SP09, IS09) were slightly pollutiondegraded. Although sediment chemistry levels were low, the infauna were modified (highly modified in the case of IS09) and there was moderate sediment toxicity. These data indicated that changes observed in the infauna may have been at least partly due to pollution, and that these stations were therefore slightly impacted.

The remaining 2 stations (IS02, IS05) were the most pollution-degraded. The infauna showed a high level of modification, and sediment chemistry levels were moderate. At Stn IS02 bioassay responses were highly elevated, indicating that this station was of more concern than IS05, where bioassay responses were only moderately elevated. Although there were substantial grain size differences, the bioassays indicated that these stations were toxic. Therefore, while the benthos may have been altered in response to sediment texture, they were also likely responding to the toxic conditions.

On the basis of the present study, the Islais Waterway site was $58 \times$ more degraded than the San Pablo Bay site and $42 \times$ more degraded than the Oakland 


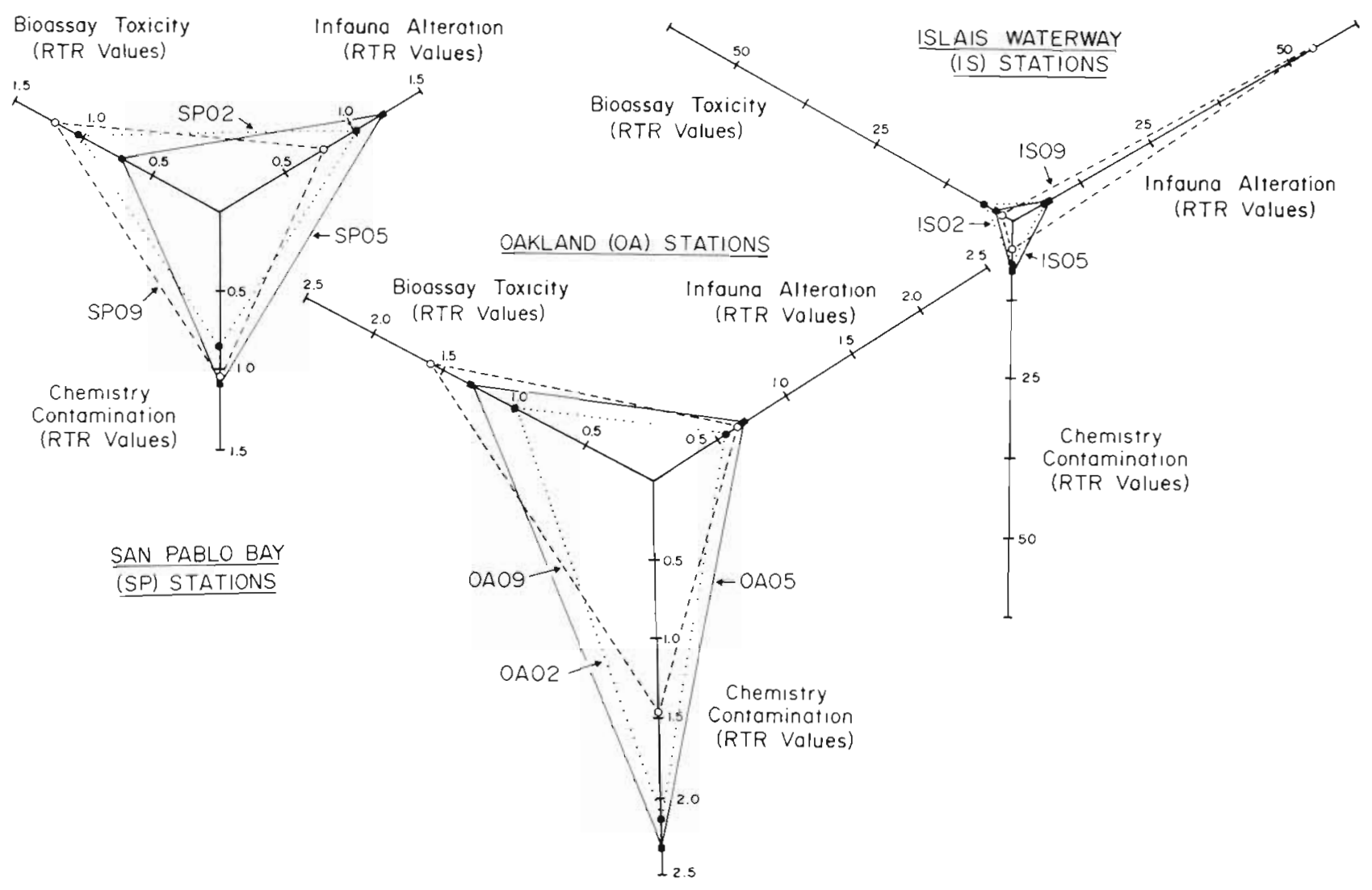

Fig. 6. The Sediment Quality Triad determined for each station at each of the 3 study sites. Chemistry Ratio-to-Reference (RTR) values are from Table 6; bioassay RTR values are from Table 8; infauna RTR values are from Table 9. The San Pablo Bay and Oakland stations are plotted on the same scale; Islais Waterway stations are plotted on a scale $1 / 25$ the size of the other 2 sites

Fig. 7. The Sediment Quality Triad determined for each of the 3 study sites. Chemistry Ratio-toReference (RTR) values are from Table 6; bioassay RTR values are from Table 8 ; infauna RTR values are from Table 9

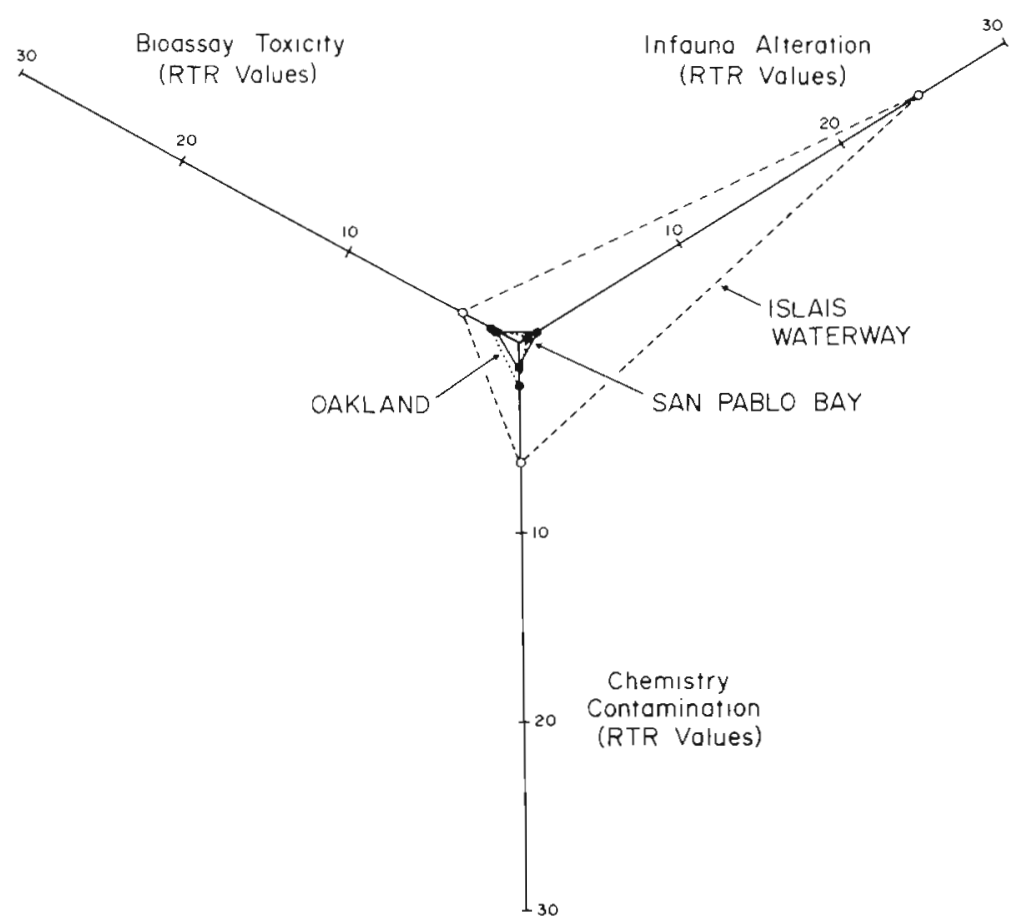


site. The Oakland site was $1.4 \times$ more degraded than the San Pablo Bay site. Changes in pollution-induced degradation over time can be assessed by comparing Triad values (=triangle areas) on the same scale over different time periods.

The data presentation in Fig. $6 \& 7$ also provides a test of the hypothesis that formed the basis of this study. This hypothesis was that all 3 types of Triad measures (bioassay, chemistry, benthos) would be needed to determine pollution-induced degradation; that we could not predict one or 2 measures based on the data from just one. Our null hypothesis $\left(\mathrm{H}_{0}\right)$, expressed in terms of these 2 figures, would thus be that the triangles are parallel. For $\mathrm{H}_{0}$ to be accepted, the lines forming the triangles in the case of each of the 3 within-site plots in Fig. 6 and the between-site plot in Fig. 7 should be parallel. As is apparent from the figures, the lines are not parallel. Thus $\mathrm{H}_{\mathrm{o}}$ is rejected.

\section{CONCLUSIONS}

The difficulty in most pollution investigations lies in obtaining information that will clearly identify those sites where actual (biological) harm to the receiving environment has occurred or is occurring due to contamination. Bulk chemical analyses measure contamination and cannot be used by themselves to determine pollution, as illustrated by the data obtained in this study for San Francisco Bay. By themselves, the Islais Waterway sediment chemistry data, although the highest of any measured in this study, might not seem of major concern compared to the much higher maximum levels measured by others in other contaminated areas of the West Coast (e.g. parts of Puget Sound and the Southern California Bight).

However, the results of the bioassays (which are performed in worst-case conditions in a laboratory), leave no doubt that the sediments from the Islais Waterway site were toxic. Therefore, they likely pose a threat to the biota at that site. Even these data could be discounted, however, as overestimating 'real world' impacts or using inappropriate organisms that do not actually live in the affected areas, or having end-points that are not indicative of in situ effects. Also, it appears that the bioassay data taken alone would have overestimated the degree of contamination of the Islais Waterway site. The benthic community data clearly showed that the infauna at the Islais Waterway site (where the highest levels of contamination and toxicity were recorded) were substantially altered relative to communities observed at other sites. However, we observed that there were differences in the sediment texture among some sites. Taken alone, the infaunal alterations at the Islais Waterway site could have been attributed to the sediment texture.

The benthic data from San Francisco Bay provided necessary information to the Triad, but they also provided a good example of why benthic data alone cannot be used to determine pollution-induced degradation. All of the sites sampled, including the reference site, had benthic communities that were markedly different than those observed in similar substrates in other West Coast areas. These differences are to be expected, since the Bay is a large shallow estuary with considerable salinity changes over short time periods and wind-driven scouring (McCulloch et al. 1970, Nichols et al. 1986). Thus, they could be interpreted to reflect a normal response to the particular habitats in the Bay. Without the sediment chemistry and bioassay data the cause of these differences in the benthos could not be determined. The importance of the Triad in this regard is emphasized when considering comments by previous investigators concerning use of the San Francisco Bay benthos for determining pollution. Nichols $(1979,1985)$ noted that natural perturbations easily mask possible anthropogenic effects. Nichols \& Thompson (1985) could not, in 10 yr of observation of a mudflat community in the Bay, differentiate benthic community change due to other than catastrophic pollution events from natural variation.

Acknowledgements. We gratefully acknowledge the technical assistance of S. Cross, D. Mitchell, J. Morgan, C. Barlow, G. Vigers, V. Funk, E. Gerencher and I. Watson of E.V.S. Consultants. Word processing was done by M. Mees, drafting by C. Siemens. We thank A. Kobayashi of Ecological Analysts for assistance in field sampling. Chemical analyses were conducted by Weyerhaeuser Analytical Laboratories, and we particularly thank S. Vincent for his assistance. The paper was reviewed by $\mathrm{H}$. White, A. Benedict, G. Arbios, J. O'Connor and A. Mearns of NOAA, and 4 anonymous referees, and we thank them for their constructive criticisms.

\section{LITERATURE CITED}

APHA (1985). Standard methods for the examination of water and wastewater, 15 th edn. American Public Health Association, Washington, D.C.

ASTM (1985a). Standard methods for particle-size analysis of soils, method D-422. In: Annual book of ASTM standards, Vol. 04.08. American Society for Testing and Materials, Philadelphia, Pensylvania, p. G3-G13

ASTM (1985b). Standard practice for conducting static acute toxicity tests with larvae of four species of bivalve molluscs. In: Annual book of ASTM standards, water and environmental technology, Vol. 11.04. American Society for Testing and Materials, Philadelphia, Pennsylvania, p. $259-275$

Battelle (1986). Reconnaissance level assessment of selected sediments from Puget Sound. Report prepared for U.S. EPA, Region 10, Seattle, Washington

Bellan-Santini, D. (1980). Relationship between populations of amphipods and pollution. Mar. Pollut. Bull. 11: 224-227 
Chapman, P. M. (1986). Sediment quality criteria from the sediment quality triad - an example. Environm. Toxicol. Chem. 5: 957-964

Chapman, P. M., Dexter, R. N., Kathman, R. D., Erickson, G A. (1985). Survey of biological effects of toxicants upon Puget Sound biota. IV. Interrelationships of infauna, sediment bioassay and sediment chemistry data. U.S. Dept. of Commerce, NOAA Tech. Memo. NOS OMA-9

Chapman, P. M., Dexter, R. N., Cross, S. F., Mitchell, D. G. (1986). A field trial of the Sediment Quality Triad in San Francisco Bay. U.S. Dept. of Commerce, NOAA Tech. Memo. NOS OMA 25

$\mathrm{CH} 2 \mathrm{M}$-Hill (1979). Bayside overflows. Report prepared for the City and County of San Francisco, California

Dowdy, S., Wearden, S. (1983) Statistics for research. John Wiley and Sons, New York

Eggiman, J. U., Betzer, C. L. (1976). Decomposition and analysis of refractory oceanic suspended materials. Analyt. Chem. 48: 886-890

EPA/CE (1981). Procedure for sulfides in sediment samples In: Procedures for handling and chemical analysis of sediment and water samples. Tech. Report EPA/CE-81-1, Environmental Laboratory, U.S. Army Engineers Waterways Experiment Station, Vicksburg, Mississippi, p. 3/ $242-3 / 247$

Gray, J. S. (1981). Detecting pollution-induced changes in communities using the log-normal distribution of individuals among species. Mar. Pollut. Bull. 12: 173-176

Heesen, T. C., Young, D. R. (1977). Precision of chlorinated hydrocarbon measurements. In: Coastal water research project annual report 1977. Southern California Coastal Water Research Project, El Segundo, California, p. 69-74

Hershelman, G. P., Jan, T. K., Schafer, H. A. (1977). Pollutants in sediments off Palos Verdes. In: Coastal water research project annual report 1977. Southern California Coasta Water Research Project, El Segundo, California, p. 63-68

Jañ, T. K., Hershelmañn, G. P. (1980). Tîace mietàls iñ surface sediments of Santa Monica Bay. In: Coastal water research project biennial report, 1979-1980. Southern California Coastal Water Research Project, El Segundo, California, p. 171-195

Jeffrey, D. W., Wilson, J. G., Harris, C. R., Tomlinson D. R (1985). The application of two simple indices to Irish estuary pollution status. In: Wilson, J. G., Halcrow, W. (ed.) Estuarine management and water quality. Plenum Press, New York, p. 147-162

Keith, L. H., Crummett, W., Deegan, J., Libby, R. A., Taylor, J. K., Wentler, G. (1983). Principles of environmental analysis. Analyt. Chem. 55: 2210-2218

Liu, D. H. W., Martin, K. D., Norwood, C. R. (1975). San Francisco Bay benthic community study, technical evaluation. San Francisco District, U. S. Army Corps of Engineers contract DACW07-74-C-00005, San Francisco

Long, E. R. (1985). Status and trends in sediment toxicity in Puget Sound. In: Oceans '85: Ocean engineering and the environment. Marine Technology Society and IEEE Ocean Engineering Society, Washington, D. C., p. 919-925

Long, E. R., Chapman, P. M. (1985). A Sediment Quality Triad: measures of sediment contamination, toxicity and infaunal community composition in Puget Sound. Mar. Pollut. Bull. 16: 405-415

MacLeod, W. D., Brown, D. W., Friedman, A. J., Maynes, O., Pearce, R. W. (1984). Standard analytical procedures of the NOAA (National Oceanic and Atmospheric Administration) National Analytical Facility, 1984-1985: extractable toxic organic compounds. U.S. Dept. of Commerce, NOAA-TM-NMFS-F/NWC-64
Malins, D. C., McCain, B. B., Brown, D. W., Sparks, A. K Hodgins, H. O. (1980). Chemical contaminants and biological abnormalities in central and southern Puget Sound. U. S. Dept. of Commerce, NOAA Tech. Memo OMPA-2

Malins, D. C., McCain, B. B., Brown, D. W., Sparks, A. K Hodgins, H. O., Chan, S-L (1982). Chemical contaminants and abnormalities in fish and invertebrates from Puget Sound. U. S. Dept of Commerce, NOAA Tech. Memo. OMPA-19

Malins, D. C., McCain, B. B., Brown, D. W., Chan, S-L, Myers, M. S., Landahl, J. T., Prohaska, P. G., Friedman, A. J. Rhodes, L. D., Burrows, D. G., Gronlund, W. D., Hodgins, H. O. (1984). Chemical pollutants in sediments and diseases of bottom dwelling fish in Puget Sound, Washington. Environm. Sci. Technol. 18: 705-713

McCulloch, D. S., Peterson, D. H., Carlson, P. R., Coromos, T. J. (1970). A preliminary study of the effects of water circulation in the San Francisco Bay estuary. U. S. Geological Survey Circular 637-A

McGreer, E. R. (1979). Sublethal effects of heavy metal contaminated sediments on the bivalve Macoma balthica (L.). Mar. Pollut. Bull. 10: 259-262

Mearns, A. J., Swartz, R. C., Cummins, J. M., Dinnell, P. A. Plesha, P., Chapman, P. M. (1986). Inter-laboratory comparison of a sediment toxicity test using the marine amphipod Rhepoxynius abronius. Mar. environm. Res. 18 13-37

Miller, R. G. (1966). Simultaneous statistical inference McGraw-Hill Co., New York, New York

Mills, E. R. (1969). The community concept in marine zoology, with comments on continua and instability in some marine communities: a review. J. Fish. Res. Bd Can. 26: $1415-1428$

Misitano, D. (1983). Effects of contaminated sediments on reproduction of a marine copepod. In: U. S. Dept. of Commerce, ivoAA/Nivifs Quarterly Repurt Oct.-Dec. 1963, p. $26-28$

Mitchell, D. G., Morgan, J. D., Vigers, G. A., Chapman, P. M. (1985). Acute toxicity of mine tailings to four marine species. Mar. Pollut. Bull. 16: 450-455

Neff, J. M., Cornaby, B. W., Vaga, R. M., Gulbransen, T. C., Scanlon, J. S., Bean, D. J. (in press). An evaluation of the screening level concentration approach to derivation of sediment quality criteria for freshwater and saltwater ecosystems. In: Tenth aquatic toxicity symposium, ASTM STP. American Society for Testing and Materials, Philadelphia

Nichols, F. H. (1979). Natural and anthropogenic influences on benthic community structure in San Francisco Bay. In: Conomos, T. J. (ed.) San Francisco Bay: the urbanized estuary. AAAS, San Francisco, p. 409-426

Nichols, F. H. (1985). Abundance fluctuations among benthic invertebrates in two Pacific estuaries. Estuaries 8: 136-144

Nichols, F. H., Thompson, J. K. (1985). Persistence of an introduced mudflat community in south San Francisco Bay, California. Mar. Ecol. Prog. Ser. 24: 83-97

Nichols, F. H., Cloern, J. E., Luoma, S. N., Peterson, D. H. (1986). The modification of an estuary. Science 231: $567-573$

Pearson, T. H., Rosenberg, R. (1978). Macrobenthic succession in relation to organic enrichment and pollution of the marine environment. Oceanogr. mar. Biol. A. Rev. 16: 229-311

Pielou, E. C. (1966). Species diversity and pattern diversity in the study of ecological succession. J. theor. Biol. 10 $370-383$ 
Quinlan, E. A., Chapman, P. M., Dexter, R. N., Konasewich, D. E., Ebbesmeyer, C. C., Erickson, G. A., Kowalski, B. R., Silver, T. A. (1985). Toxic chemicals and biological effects in Puget Sound: status and scenarios for the future. U. S. Dept. of Commerce, NOAA. Tech. Memo. OMA-10

Romberg, G. P., Pavlou, S. P., Shokes, R. F., Hom, W., Crecelius, E. A., Hamilton, P., Gunn, J. T., Meunch, R. D., Vinelli, J. (1984). Toxicant pretreatment planning study technical report $\mathrm{CI}$ : presence, distribution and fate of toxicants in Puget Sound and Lake Washington. Municipality of Metropolitan Seattle, Seattle

Rygg, B. (1985). Distribution of species along pollutioninduced diversity gradients in benthic communities in Norwegian fjords. Mar. Pollut. Bull. 16: 469-474

Satsmadjis, J., Voutsinou, Taliadouri, F. (1985). An index of metal pollution in marine sediments. Oceanologica Acta 8: $277-284$

Spies, R. B., Rice, D. W., Montagne, P. A., Ireland, R. R., Felson, J. S., Healy, S. K., Lewis, P. R. (1985). Pollutant body burdens and reproduction in Platichthys stellatus from San Francisco Bay. Report prepared by the Lawrence Livermore National Laboratory, California

Sprague, J. B. (1969). Measurement of pollutant toxicity to fish I. Bioassay methods for acute toxicity. Wat. Res. 3: 793-821

Steel, R. G. D., Torrie, J. H. (1960). Principles and procedures of statistics. McGraw-Hill Book Co., New York, New York
Swartz, R. C., DeBen, W. A., Sercu, K. A., Lamberson, J. O. (1982). Sediment toxicity and the distribution of amphipods in Commencement Bay, Washington, USA. Mar. Pollut. Bull. 13: 359-364

Swartz, R. C., DeBen, W. A., Phillips, J. K., Lamberson, J. O., Cole, F. A. (1985). Phoxocephalid amphipod bioassay for marine sediment toxicity. In: Cardwell, R. D., Purdy, R., Bahner, R. C. (ed.) Aquatic toxicology and hazard assessment: seventh symposium. ASTM STP 854. American Society for Testing and Materials, Philadelphia

Tetra Tech. (1985). Commencement Bay Nearshore/Tideflats remedial investigation. Report (5 volumes) prepared for Washington Department of Ecology and U.S. Environmental Protection Agency, EPA-910/9-85-134a

U. S. EPA (1984a). Contract laboratory protocol methodologies IFB WA 84 J091/J092, Washington, D. C.

U. S. EPA (1984b). Method 1625. Semi-volatile organic compounds by isotope dilution gas chromatography mass spectrometry. 40 CFR Part 136. Federal Register 49: 184

Warwick, P. M. (1986). A new method for detecting pollution effects on marine macrobenthic communities. Mar. Biol. 92: $557-562$

Weyerhaeuser (1985). Determination of total carbon in solid and semi-solid material. Analytical method 1801-02, Analytical Laboratories, Weyerhaeuser Technology Center, Tacoma, Washington 